\title{
Economic and Social Rights in National Constitutions
}

\author{
Ran Hirschl, Courtney Jung and Evan \\ Rosevear
}

Version Post-print/accepted manuscript

Citation Ran Hirschl, "Economic and Social Rights in National Constitutions" (published version) (2015) 62 American Journal of Comparative Law 1043.

Publisher's Statement This is a pre-copyedited, author-produced version of an article accepted for publication in the American Journal of Comparative Law following peer review. The version of record [Ran Hirschl, "Economic and Social Rights in National Constitutions" (2015) 62 American Journal of Comparative Law 1043] is available online at: https://doi.org/10.5131/ajcl.2014.0030

How to cite TSpace items

Always cite the published version, so the author(s) will receive recognition through services that track citation counts, e.g. Scopus. If you need to cite the page number of the author manuscript from TSpace because you cannot access the published version, then cite the TSpace version in addition to the published version using the permanent URI (handle) found on the record page.

This article was made openly accessible by $U$ of $T$ Faculty. Please tell us how this access benefits you. Your story matters. 


\title{
Economic and Social Rights in National Constitutions
}

\author{
Courtney Jung \\ Professor of Political Science \\ University of Toronto \\ courtney.jung@utoronto.ca \\ (416) 978-2381 \\ Corresponding Author \\ Ran Hirschl \\ Canada Research Chair and Professor of Political Science \& Law \\ University of Toronto \\ ran.hirschl@utoronto.ca \\ Evan Rosevear \\ $\mathrm{JD} / \mathrm{PhD}$ (Political Science) Candidate \\ University of Toronto \\ evan.rosevear@utoronto.ca
}

Authors' Note: We thank the Journal's Editor and anonymous referees for their thoughtful comments and suggestions on an earlier version of this paper. We gratefully acknowledge comments on the dataset and earlier versions of this paper from Philip Alston, Dennis Davis, Varun Gauri, Malcolm Langford, Patrick Macklem, Catherine Valcke, Chris Cochrane, and Peter John Loewen. Advice, assistance, and feedback were also provided by the members of the TIESR Advisory Board, and by our partners: The Comparative Constitutions Project; The Center for Economic and Social Rights; and The CIRI Human Rights Data Project. We are grateful to Salvator Cusimano for his meticulous work on compiling the initial dataset and the assistance of Vuk Radmilovic with Slavic and Milena Pandy-Szekeres with Hungarian translation. All responsibility for errors remains with the authors. This project was funded by a grant from the Social Sciences and Humanities Research Council of Canada. 


\section{ABSTRACT}

Much has been written about the global convergence on constitutional supremacy, and the corresponding rise of an apparently universal constitutional discourse, primarily visible in the context of rights. In this paper, we examine the global constitutional homogeneity claim with respect to economic and social rights. Based on a new and unique dataset that identifies the status of sixteen distinct economic and social rights in the world's constitutions (195 in total), we make four arguments. First, although economic and social rights have grown increasingly common in national constitutions, not all ESRs are equally widespread. Whereas a right to education is so common as to be practically universal, rights to food or water are still very rare. Second, constitutions accord ESRs different statuses, or strengths. Roughly one third of countries identify all economic and social rights as justiciable, another third identify all ESRs as aspirational, and the last third identify some ESRs as aspirational and some as justiciable. Third, legal tradition - whether a country has a tradition of civil, common, Islamic or customary lawis a strong predictor of whether a constitution will have economic and social rights and whether those rights will be justiciable. Fourth, whereas regional differences partly confound the explanatory power of legal traditions, region and legal tradition retain an independent effect on constitutional entrenchment of ESR. We conclude by suggesting that despite the prevalence of economic and social rights in national constitutions, as of 2013 there is still considerable variance with respect to the formal status, scope and nature of such rights. Because the divergence reflects lasting determinants such as legal tradition and region, it is likely to persist. 


\section{INTRODUCTION}

In the last four decades, the world has witnessed a rapid spread of constitutionalism and judicial review. Constitutional supremacy, long a pillar of the American political order, is now shared in some form by at least one hundred and forty-two countries and several supranational entities across the globe. ${ }^{1}$ Most of these polities can boast the recent adoption of a constitution or a constitutional revision that contains a bill of justiciable rights and enshrines some form of active judicial review. The astounding global spread of constitutions and bills of rights has generated renewed interest in economic and social rights (ESRs) among academics, jurists, and policy-makers. ${ }^{2}$ ESRs promise access to housing, healthcare, education, and social security, and guarantee rights to unionize, strike, and fair wages. Along with civil and political rights, they are enshrined in the Universal Declaration of Human Rights, as well as in several other key international and regional human rights regimes. Theoretically at least, they bind states signatory to the International Covenant on Economic, Social, and Cultural Rights (ICESCR).

Amartya Sen built on the foundation of economic and social rights to develop the "capabilities approach" to quality of life assessment that has been adopted by the Human Development Report of the United Nations Development Programme (UNDP). The capabilities approach stresses the ability to live a decent life, to be adequately nourished, and to have access to health care and shelter as essential preconditions to the enjoyment of any other rights and freedoms. Nearly all new democracies, and several established ones, have included some form of ESRs in their constitutions, committing their governments, at least formally, to the realization of minimum standards of social welfare. Most also include a generic protection of "the right to life" or of "human dignity," either in lieu of, or in addition to, a set of concrete ESRs. As one observer recently put it: "in the space of two decades, social rights have emerged from the shadows and margins of human rights jurisprudence." ${ }^{3}$

The renaissance of economic and social rights is reflected in the lively conversation concerning the philosophical foundations of subsistence rights, as well as in a burgeoning literature on how the provision of basic needs ought to be addressed through rights protections and constitutional jurisprudence. These accounts range from exploration by prominent philosophers, including Amartya Sen, Henry Shue, Martha Nussbaum, John Rawls, and Jeremy Waldron, into the moral justifications for the provision of basic needs, ${ }^{4}$ to explorations of how

\footnotetext{
${ }^{1}$ At the country level, this assertion is based on the constitutional entrenchment of at least one justiciable Economic or Social Right.

${ }^{2}$ Terminological clarity has not been a feature of this renewed interest. In addition to economic and social rights, these rights are variously referred to as "second generation rights", "(social) welfare rights", "subsistence rights", "positive rights", and "social rights." They are also frequently included under the ever-expanding umbrella of "human rights".

3 Social Rights Jurisprudence: Emerging Trends in International and Comparative LaW, (Malcolm Langford ed., 2008).

${ }^{4}$ Amartya Sen, Equality of What?, in LiBerTy, EQuality, AND LAW: SELECTED TANNER LeCtures ON Moral Philosophy 197-220 (1987); AmARTya Sen, InEQuality REEXAMined (1992); MARTHA C. Nussbaum, WomeN
} 
courts ought to balance principled and pragmatic approaches to advance progressive notions of distributive justice, ${ }^{5}$ and to assessments of judicial reasoning in several staple ESR judgments from South Africa or India. ${ }^{6}$

However, a basic building block of this discussion is absent: a systematic description and analysis of the entrenchment of these rights in contemporary constitutions. The fundamental questions that have gone unanswered include: how common is the broad category of economic and social rights in constitutions around the world? Are there differences in the specific social rights that are guaranteed constitutional protection? What accounts for variation in the scope and nature of ESR constitutional protections across polities? These and other related questions prod the most basic element of the social rights universe, yet they remain surprisingly underexplored and under-theorized.

This paper addresses that gap by introducing and analyzing a comprehensive dataset of all ESR provisions in the world's written constitutions in effect on 1 January 2013. The Toronto Initiative for Economic and Social Rights (TIESR) dataset quantifies the constitutional status of economic and social rights in 195 contemporary national constitutions. It identifies sixteen separate economic and social rights, and codes them according to their constitutional status as absent, aspirational, or justiciable. ${ }^{7}$

Our analysis tracks the global spread and frequency of ESRs and traces patterns of ESR constitutional entrenchment with respect to individual rights, models of entrenchment, legal traditions, and regions. We identify four key patterns. First, although economic and social rights have grown increasingly common in national constitutions, ${ }^{8}$ not all ESRs are equally widespread. Whereas a right to education is so common as to be practically universal, rights to food or water are still very rare. These patterns of entrenchment suggest that the common practice of classifying economic and social rights as a single category of "positive" or "second generation"

and Human Development: The Capabilities Approach (2001); Henry Shue, Basic Rights: Subsistence, AfFluence, AND U.S. Foreign Policy (1980); Jeremy Waldron, Welfare and the Images of Charity, 36 PHIL. Q. 463-482 (1986); John Rawls, The LaW OF Peoples: With “The Idea of Public Reason RevisiteD” (2001).

${ }^{5}$ Mark V. Tushnet, Weak Courts, Strong Rights: Judicial ReVIEW and SOCIal Welfare Rights in Comparative Constitutional LaW (2007); Katharine G. Young, Constituting EConomic and Social RightS (2012); JEFF KING, JUDGING SOCIAL RIGHTS (2012).

${ }^{6}$ The canonical ESR judgments of the South African Constitutional Court are Minister of Health and Others v Treatment Action Campaign and Others (No 1), [2002] ZACC 5 (2002); Government of the Republic of South Africa and Others v Grootboom and Others, [2000] ZACC 19; Soobramoney v. Minister of Health (KwaZuluNatal), ZACC 17 (1997); two often cited examples of ESR jurisprudence by the Indian Supreme Court are Olga Tellis v. Bombay Municipal Corporation, [1985] 3 SCR 545; Unni Krishnan v. State of Andhra Pradesh, [1993] 1 SCC 645 (1993).

${ }^{7}$ A detailed description of coding procedures is outlined in: Courtney Jung, CODING MANUAL: A DESCRIPTION OF THE METHOdS AND DeCisions UsED to BuILD a CROSS-NATIONAL DATASET OF ECONOMIC AND SOCIAL RightS IN DEVELOPING COUNTRY CONSTITUTIONS (2010), http://www.tiesr.org/Data/coding\%20manual\%20nov\%209.pdf.

${ }^{8}$ David S. Law, Generic Constitutional Law, 89 MinN. L. ReV. 652 (2005); Mark Tushnet, The Inevitable Globalization of Constitutional Law, 49 VA. J. INT’L. L. 985-1006 (2008). 
rights is overly broad. ${ }^{9}$ These rights are more appropriately, we argue, categorized into four subgroups: economic rights, standard social rights, non-standard social rights, and environmental rights.

Second, constitutions accord ESRs different statuses, or strengths. Roughly one third of the countries in our dataset identify all of their economic and social rights as justiciable, another third identify some ESRs as aspirational and some as justiciable, and the remaining third is split more or less evenly between those constitutions containing only aspirational ESRs and those containing fewer than two.

Third, legal tradition-specifically, whether a country has a tradition of civil law common law, or a mixture of one or both with other traditions-is a strong predictor of whether a constitution will have economic and social rights and whether those rights will be justiciable. All else being equal, our analysis shows that constitutions in purely civil law countries incorporate nearly four times as many ESRs as purely common law countries, a factor that increases to more than five times when only justiciable rights are considered. The incorporation of Islamic and customary law appears to mitigate the extremes of both.

Fourth, regional differences partly confound the explanatory power of legal traditions because the two regions with the largest number of ESRs, Latin America and the Postcommunist states, are also all civil law countries. ${ }^{10}$ Although some regions do not exhibit a particular "norm" of ESR entrenchment, Latin America and the Postcommunist states have strong regional norms that are at least partly independent of the fact that they also have civil law traditions. Importantly, legal tradition continues to have independent effect when region is controlled for, and region retains independent effect when we control for legal tradition.

The remainder of the paper is divided into seven parts. In part II, we offer an overview of the dataset's contents and outline the method of its collection. In part III, we identify four "families" of economic and social rights, based on their function, frequency and tendency to cluster. In part IV, we identify three constitutional "models" of entrenchment: justiciable, aspirational, and mixed. In part $\mathrm{V}$ we examine the significance of legal tradition in accounting for some of the variance in the scope and nature of ESR protection in the world's constitutions. In contrast to the global constitutional convergence argument, we find considerable differences in the constitutional protection of ESRs along legal tradition lines, and then attempt to provide an explanation as to why legal tradition may matter in accounting for the mode of constitutional ESR protection. In part VI we identify significant regional variation in the constitutional

\footnotetext{
${ }^{9}$ David S Law \& Mila Versteeg, The Evolution and Ideology of Global Constitutionalism, 99 CALIF. L. REv. 11631258 (2011). There is also a degree of terminological confusion in this. On the one hand, human rights are often classified as first generation (civil and political), second generation (economic and social), and third generation (collective/group). See, e.g. Karel Vasak, A 30-year Struggle: The Sustained Effort to Give Force of Law to the Universal Declaration of Human Rights, UNESCO COURIER 28-32 (1977). At the same time, in certain circles T.H. Marshall's classification of civil rights as first generation rights, political rights as second generation rights and social welfare rights as third generation rights is a common referent. T. H. Marshall, Citizenship and Social Class, in ClAss, CiTIZENSHIP AND SOCIAL DEVELOPMENT: ESSAYS By T.H. MARSHALL 62-122 (1964).

${ }^{10}$ With the exception of Belize.
} 
protection of ESRs (the constitutions of Latin American and Postcommunist countries, for example, are more likely to include an elaborate constitutional matrix of ESR protection than countries in other regions). In part VII, we employ statistical analysis as a means of supporting the arguments developed throughout the piece. Finally, in part VIII we propose some theoretical refinements to existing arguments in comparative constitutional law concerning the status of ESRs in world constitutions and global constitutional convergence.

\section{METHODOLOGY}

The TIESR dataset includes the entire corpus of national constitutions and constitutional documents (such as the UK Human Rights Act) serving as de jure or de facto higher law. Countries officially identified as dependencies, overseas territories, or foreign departments were excluded from the dataset. The 195 constitutions represented in the dataset offer a snapshot of the contemporary constitutional model of ESR entrenchment effective January 1, $2013 .^{11}$ Compared with other constitutional datasets, ${ }^{12}$ the scope of the TIESR dataset is limited in the sense that it codes only ESRs in constitutions that are currently in force. It is more expansive, however, in that it codes the constitutional status, or strength, of particular ESRs as aspirational or justiciable. Justiciable rights are identified in the constitution as enforceable through the domestic court system and subject to legal remedy. ${ }^{13}$

Although there is some textual ambiguity with respect to the formal legal status of rights, contemporary constitutions can and do entrench ESRs, along with rights more generally, as justiciable or aspirational. ${ }^{14}$ These distinctions are normally fairly clear, and are signalled by three principal textual markers. First, a constitution must include a mechanism of judicial review for any right to be coded as justiciable. Second, a constitution must state, implicitly or explicitly, that individuals have the power to initiate judicial review. Finally, a constitution may make a distinction between justiciable and aspirational rights, depending on where they are found in the constitution. Constitutions often identify some rights as "fundamental" (and justiciable) or locate rights in different sections of the constitution, identifying some sections as justiciable and

\footnotetext{
${ }^{11}$ This assertion is based on a survey of the Constitutions of the Countries of the World database, the World Constitutions Illustrated database, and the CIA World Fact Book supplemented by queries of colleagues, the review of contemporary literature, a series of news alerts, and reference to the websites of relevant apex courts, legislatures, and executives. The survey instrument used to code the relevant constitutional documents was adapted from the template created and used by Elkins, Ginsburg and Melton in the construction of the Comparative Constitutions Project (CCP).

12 Zachary ElKins, Tom Ginsburg \& James Melton, The Comparative Constitutions Project:A CrossNATIONAL HISTORICAL DATASET OF WRITTEN CONSTITUTIONS (2008), http://www.comparativeconstitutionsproject.org/files/surveyinstrument.pdf; Law and Versteeg, supra note

${ }^{13}$ Christian Courtis, The Right to Food as a Justiciable Right: Challenges and Strategies, 11 inMax PlanCK YEARBOOK OF UNITED NATIONS LAW , 318 (Armin von Bogdandy\&RüdigerWolfrum eds., 2007); Jackbeth K Mapulanga-Hulston, Examining the Justiciability of Economic, Social and Cultural Rights, 6 INT'L. J. HuM. RTs.2948, 36 (2002).

${ }^{14}$ James Melton et al., On the Interpretability of Law: Lessons from the Decoding of National Constitutions, BRIT. J. POLIT. SCI. 1-25 (2012).
} 
others as aspirational. In order to be coded as justiciable, a right had to meet each of the three criteria outlined above. Table 1 specifies the criteria used to code each individual right.

Table 1. Coding Values

\begin{tabular}{|c|c|c|}
\hline Value & Label & Criteria \\
\hline 2 & “Justiciable" & $\begin{array}{l}\text { The government can be taken to court for failing to guarantee the } \\
\text { economic and social rights promised in the constitution. } \\
\text { - Citizens have legal recourse to ensure the fulfillment of their } \\
\text { constitutional rights; usually a mechanism for judicial review enshrined } \\
\text { in the constitution. }\end{array}$ \\
\hline 1 & $\begin{array}{l}\text { “Aspirational,” } \\
\text { or "Directive Principle } \\
\text { of State Policy” }\end{array}$ & $\begin{array}{l}\text { Enumeration of constitutional rights intended to guide state policy } \\
\text { and/or express ideals, but they are not binding. Directs government to } \\
\text { take social welfare into account when making policy decisions, but } \\
\text { creates no obligation to do so. } \\
\text { - Citizens do not have legal recourse to ensure the fulfillment of their } \\
\text { constitutional rights. } \\
\text { - ESRs are not considered fundamental rights. }\end{array}$ \\
\hline 0 & “Absent” & $\begin{array}{l}\text { The item is not mentioned in the constitution, either as a justiciable, or } \\
\text { as an aspirational right or directive principle. }\end{array}$ \\
\hline
\end{tabular}

Our coding took only constitutional text into account, and did not examine the existence of ESR case law in a particular country. Although the textual status of a right is no guarantee of its actual implementation, constitutional texts offer clues regarding the relative standing of particular rights, the scope of state responsibility, and the appropriate role of the law. Moreover, the documentation of their formal status is an important step in any attempt to understand the role of formal law in judicial decision-making.

\section{ASPIRATIONAL AND JUSTICIABLE MODELS OF ENTRENCHMENT}

Whether particular rights are in fact justiciable-enforceable through the domestic court system and subject to legal remedy-depends in part on factors beyond the constitution alone. ${ }^{15}$ Nevertheless, constitutional texts also tend to specify the formal status of ESRs, signalling what relative status is accorded to different rights, what relative responsibility, with respect to rights provision, is accorded to the court, and the scope of state obligation for human well-being. Even if constitutionally entrenched justiciability does not guarantee legal remedy, it does normally establish where economic and social rights have formally co-equal status with other justiciable rights and freedoms in the constitution. Since ESRs have long been considered subordinate to classic civil liberties, their comparative standing within a constitution may tell us more about their relative contemporary status than simply measuring their mere presence or absence.

\footnotetext{
15 See, e.g. Charles Epp, The Rights Revolution: LAwYers, ACTIVISTS, AND Supreme Courts IN Comparative Perspective (1998); VarunGauri \& Daniel M. Brinks, Introduction: The Elements of Legalization and the Triangular Shape of Social and Economic Rights, inCOURTING SOCIAL JUSTICE: JUDICIAL ENFORCEMENT OF SOCIAL AND ECONOMIC RightS IN THE DEVELOPING WORLD 1-37 (VarunGauri\& Daniel M. Brinks eds., 2008); Gerald N. Rosenberg, The Hollow Hope: Can Courts Bring About Social Change? (2 ed. 2008).
} 
Of the 158 constitutions that contain more than one economic and social right, roughly two thirds confer equal strength - either justiciable (67) or aspirational (30) - on all the ESRs they recognize. The remaining third include a mixture of justiciable and aspirational economic and social rights. Two insights can be drawn from this empirical observation. First, this highlights a novel element captured by the TIESR data: not all ESRs were born equal. Although existing datasets that include ESR incidence within constitutions record the presence or absence of judicial review in a constitution, ${ }^{16}$ they do not record which particular rights are justiciable, and which are not. Constitutions themselves, however, can and do accord different status to different rights. Second, based on the justiciable-aspirational distinction, there are three distinct “models” of ESR incorporation: purely justiciable, purely aspirational, and mixed.

This three-fold categorization may help to establish whether the constitutional status of rights has an impact on judicial review or the capacity of individuals to seek legal remedy. The present assumption is that judicial interpretation and variance in implementation are more important than constitutional text. A relevant example in support of this proposition is the divergent interpretation of nearly identical passages in the Indian and Canadian Constitutions. ${ }^{17}$ Article 21 of the Indian Constitution states that "No person shall be deprived of his life or personal liberty except according to procedure established by law."18 Section 7 of the Canadian Constitution reads: "Everyone has the right to life, liberty and security of the person and the right not to be deprived thereof except in accordance with the principles of fundamental justice.”19 The former has interpreted the right to life and liberty in a manner imposing positive obligations on the state for the provision of material necessities to the impoverished, ${ }^{20}$ while the latter has consistently interpreted these rights as imposing limits on state action. ${ }^{21}$ Drawing similar “contra-textual” conclusions, political scientists argue that the interpretation of constitutional text is conditioned by the ideational outlook, policy preferences, institutional location and/or strategic choices of courts, politicians and policy-makers. ${ }^{22}$

There are good reasons to support these views. In many jurisdictions there is no viable or independent judiciary that can take up constitutional matters, even if constitutions include a panoply of rights. Judges may be reluctant to take up economic and social rights cases in

\footnotetext{
${ }^{16}$ ELKINS, GinsBuRg, AND Melton, supra note__ ; Avi Ben-Bassat\&MorriDahan, Social Rights in the Constitution and in Practice, 36 J. Comp. ECON.103-119 (2008); Law and Versteeg, supra note

${ }^{17}$ Ran Hirschl\& Evan Rosevear, Constitutional Law Meets Comparative Politics: Socio-Economic Rights and Political Realities, in The Legal Protection of Human Rights: Sceptical Essays 207-228, 213 (Tom Campbell \& K.D. Ewing eds., 2011).

${ }^{18}$ The CONSTITUTION OF INDIA, 1949 (AS AMENDED), INDIA (2007).

${ }^{19}$ SCHEDUle B tO THE CANADA ACT 1982, (U.K.) 1982, (1982).

${ }^{20}$ See, e.g. Olga Tellis v. Bombay Municipal Corporation, supra note

${ }^{21}$ See, e.g. Gosselin v. Quebec (Attorney General), [2002] 2 S.C.R. 429.

${ }^{22}$ See, e.g. Lee Epstein \& Tonja Jacobi, The Strategic Analysis of Judicial Decisions, 6 ANNUAL ReviEW OF LAW AND SOCIAL SCIENCE 341-358 (2010); Diana Kapiszewski, Tactical Balancing: High Court Decision Making on Politically Crucial Cases, 45 LAW \& SOC’Y REV. 471-506 (2011).
} 
particular, because they may impinge on the authority of the executive or the legislature to make decisions about budget allocation. Judges may alternatively take an activist stance toward economic and social rights, transforming aspirational principles into justiciable guarantees. Each of these possibilities is both theoretically plausible and empirically observable.

Nevertheless, if it is also true that countries with justiciable ESR constitutions generate most of the contemporary ESR case law, then there is at least a correlation between constitutionally entrenched and "real” justiciability. The secondary literature on ESR jurisprudence, as well as evidence drawn from the ESCR-Net case law database, suggest the existence of such a correlation between justiciable constitutions and actual justiciability. ${ }^{23}$ Latin American constitutions include more economic and social rights, and more justiciable economic and social rights, than any other region of the world. The region has a long standing commitment to ESRs, but such rights have only been rendered justiciable in the wave of constitution-making of the last two decades. This is partly because most Latin American countries have a provision for amparo or amparo-like mechanisms (e.g. Colombia's acción de tutela) that allows citizens to make direct application for legal relief of a violation of a right. In Colombia alone, there were 424,400 claims made in 2012, of which more than a quarter related to the right to health. ${ }^{24}$ The Constitutional Court of Colombia reviews a selection of lower court tutela claims, and has issued thousands of decisions related to economic and social rights. Although the Brazilian court has not produced a similar volume of decisions, it has issued a number of important, internationally recognized decisions, in particular with regard to the right to health. ${ }^{25}$ South Africa, too, has a formal commitment to justiciability that is matched by significant case law on ESRs. Many of the decisions that have shaped our understanding of economic and social rights, including Soobramoney, ${ }^{26}$ Grootboom, ${ }^{27}$ TAC $^{28}$ and others, were made by the South African Constitutional Court. ${ }^{29}$

The other region of the world that generates significant ESR case law is South Asia. The Supreme Court of India has been one of the most activist peak courts in the world in expanding

\footnotetext{
${ }^{23}$ SOCIAL RightS JURISPRUDENCE, supra note__ COURTING SOCIAL JUSTICE: JUdiCIAL ENFORCEMENT OF SOCIAL AND ECONOMIC RightS IN THE Developing World, (VarunGauri\& Daniel M. Brinks eds., 2008); ESCR-Net Caselaw Database: A Database of Economic, Social and Cultural Rights Related Jurisprudence, Cases and Other Decisions, INTERNATIONAL NETWORK FOR ECONOMic, SOCIAL \& CUltural Rights, http://www.escrnet.org/caselaw/.

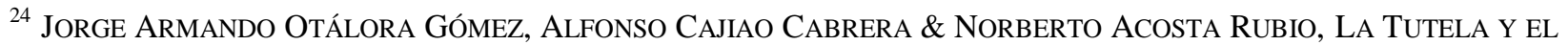
DERECHO A LA SALUD 2012 110-11 (2013).

${ }^{25}$ Varun Gauri, Social Rights and Economics: Claims to Health Care and Education in Developing Countries, 32 World Development 465-477 (2004); Mariana Mota Prado, The Debatable Role of Courts in Brazil's Health Care System: Does Litigation Harm or Help?, 41 J.L. MED. \& ETHICS 124-137 (2013).

${ }^{26}$ SOOBRAMONEY, supra note

${ }^{27}$ GROOTBOOM, supra note

${ }^{28}$ TREATMENT ACTION CAMPAIGN, supra note

${ }^{29}$ See, generally Sandra Liebenberg, South Africa: Adjudicating Social Rights Under a Transformative Constitution, in SOCIAL RIgHTS JURISPRUDENCE: EMERGING TRENDS IN INTERNATIONAL AND COMPARATIVE LAW (Malcolm Langford ed., 2008).
} 
the justiciable contours of ESR constitutional protection. ${ }^{30}$ Following the Indian lead, activist courts in Bangladesh, Sri Lanka, and Pakistan have transformed aspirational constitutional commitments into de facto justiciable rights through broad and positive interpretations of the right to life. ${ }^{31}$ The Pakistani Supreme Court began to expand legal access in the early 1990s when it stated that citizens' rights to obtain justice could be facilitated by allowing simple and direct petitions to the Supreme Court. ${ }^{32}$ If it is true that in fact there is a fairly consistent relationship between constitutional justiciability and judicial treatment of ESRs, then India and its South Asian neighbors are outliers. Because Indian courts have played such an important role in the judicial history of economic and social rights, India has cast a long shadow in this field, and has importantly shaped our perception that, at least in the ESR domain, there may be a fundamental disconnect between constitutional texts and constitutional jurisprudence. Even though constitutions do not single-handedly generate case-law, it may still be true that the "fundamental disconnect" thesis may have been overblown due to the influence of an important, but unrepresentative, single case. Keeping in mind the relevant caveats, constitutional justiciability may in fact be a reliable indicator of justiciability in practice.

\section{FAMILIES AND FREQUENCIES}

In general, economic and social rights are widely present in contemporary constitutions. More than $90 \%$ of 195 constitutions currently in force contain at least one economic and social right. $^{33}$ More surprisingly, approximately $70 \%$ of current constitutions contain at least one explicitly justiciable economic and social right, and roughly a quarter contain ten or more. Nevertheless, there is significant variation in the relative prevalence of particular rights (Table 2). Some are quite commonly enshrined in constitutions, and others are relatively rare. The right to education is the most widely enshrined ESR, present in more than three-quarters of the world's constitutions. ${ }^{34}$ The right to form or join a trade union is the second most prevalent, followed by healthcare, social security, child protection, and environmental protection. These six rights are present in more than half of all constitutions. The right to form or join a trade union is the most commonly justiciable right, identified as such in nearly two-thirds of constitutions.

\footnotetext{
${ }^{30}$ See Madhav Khosla, The Indian Constitution (2012); Madhav Khosla, Making Social Rights Conditional: Lessons from India, 10 I-CON INT’L J. CONST. L. 739-765 (2010).

${ }^{31}$ Iain Byrne \& Sara Hossain, South Asia: Economic and Social Rights Case Law of Bangladesh, Nepal, Pakistan, and Sri Lanka, inSOCIAL RighTS JURISPRUDENCE: EMERGING TRENDS IN INTERNATIONAL AND COMPARATIVE LAW 125-143, 125-26 (Malcolm Langford ed., 2008).

${ }^{32}$ Id. at 130 .

${ }^{33}$ Sixteen countries' constitutions contain no ESRs. These countries are: Australia, Brunei, Canada, France, Israel, Kiribati, Lebanon, Liechtenstein, Malaysia, Micronesia, New Zealand, Singapore, Tonga, Trinidad and Tobago, the United States, and Vanuatu.

${ }^{34}$ This paper uses three terms to describe the "strength" of economic and social rights provisions: aspirational, justiciable, and present. "Present" refers to both aspirational and justiciable rights. For example, if the right to education is aspirationally entrenched in five constitutions and justiciable in three, the right will be identified as "present" in eight constitutions.
} 
Education, Child Protection, Healthcare, Social Security, and the right to Strike are justiciable in at least one third of constitutions. At the other end of the spectrum, the right to development is the least commonly present, and second least commonly justiciable, economic and social right. This right is justiciable in nineteen countries, ${ }^{35}$ and aspirational in an additional twelve. ${ }^{36}$ The rights to land and to food and water are also relatively rare, present in less than one quarter, and justiciable in about one-tenth, of the world's constitutions.

Table 2. Frequency of Economic \& Social Rights

\begin{tabular}{llllll}
\hline \hline & \multicolumn{1}{c}{ Present } & & Justiciable & & Aspirational \\
\hline $80 \%$ & Education & $63 \%$ & Trade Union & $28 \%$ & Healthcare \\
$74 \%$ & Trade Union & $55 \%$ & Education & $27 \%$ & Environmental Protection \\
$69 \%$ & Healthcare & $47 \%$ & Child Protection & $27 \%$ & Social Security \\
$67 \%$ & Social Security & $41 \%$ & Strike & $25 \%$ & Education \\
$65 \%$ & Child Protection & $41 \%$ & Healthcare & $19 \%$ & Child Protection \\
$55 \%$ & Environmental Protection & $41 \%$ & Social Security & $16 \%$ & Housing \\
$49 \%$ & Strike & $32 \%$ & Healthy Environment & $15 \%$ & Employment Soc. Sec. \\
$48 \%$ & Healthy Environment & $32 \%$ & Fair Wage & $15 \%$ & Healthy Work \\
$47 \%$ & Employment Soc. Sec. & $31 \%$ & Employment Soc. Sec. & $13 \%$ & Leisure \\
$43 \%$ & Fair Wage & $29 \%$ & Leisure & $12 \%$ & Healthy Work \\
$42 \%$ & Leisure & $28 \%$ & Environmental Protection & $12 \%$ & Fair Wage \\
$41 \%$ & Housing & $26 \%$ & Healthy Work & $11 \%$ & Trade Union \\
$38 \%$ & Healthy Work & $25 \%$ & Housing & $9 \%$ & Strike \\
$22 \%$ & Food \& Water & $13 \%$ & Food \& Water & $9 \%$ & Food \& Water \\
$16 \%$ & Development & $10 \%$ & Development & $8 \%$ & Land \\
$15 \%$ & Land & $8 \%$ & Land & $6 \%$ & Development \\
\hline \hline
\end{tabular}

Although economic and social rights are treated as a single category of rights in international covenants and declarations, as well as most academic literature, many constitutions treat different rights differently. As a first step in our analysis of the TIESR data, we disaggregated rights into four different categories based on their frequency, conceptual similarities, and tendency to cluster.

Economic rights include the right to form or join a trade union, strike, leisure, a fair wage, a healthy work environment, and employment derived social security. These rights accrue to individuals based on their employment status, and persist only as long as they remain employed or in some relationship to work (e.g. in retirement, on maternity leave). Of the 195 constitutions in the dataset, 166 contain at least one of the six economic rights and more than half contain three or more; 134 constitutions contain at least one justiciable worker's right and 73 contain three or more. The median number of ERs present per constitution is three, the median

\footnotetext{
${ }^{35}$ Belgium, The Democratic Republic of the Congo, the Dominican Republic, Ethiopia, Finland, Georgia, Germany, Greece, Guinea, Italy, Kyrgyzstan, Madagascar, Malawi, Moldova, Nicaragua, Niger, Peru, and the Ukraine.

36 Andorra, Bulgaria, Cameroon, Cape Verde, Côte d’Ivoire, Korea (North), Montenegro, Morocco, Papua New Guinea, Somalia, Turkmenistan, and Uganda.
} 
number justiciable per constitution is one. The average number of justiciable ERs per constitution is 2.2 .

Social rights protect social well-being beyond the workplace, and are accorded to individuals on the basis of citizenship or legal immigrant status rather than employment. The TIESR dataset identifies ten social rights (SRs), which we disaggregated into three "families" based on their frequency, conceptual similarities, and tendency to appear together. The first family includes four "standard social rights" (SSRs): Education, Healthcare, Social Security, and Child Protection. By virtue of the frequency with which they are entrenched in constitutionsfour-fifths of constitutions contain at least one-we hypothesize that these are the least controversial social rights. Rights to health, education, and child protection in particular may be compellingly framed as "investments in human capital," a category of spending that was endorsed by the IMF and the World Bank even in the era of the Washington Consensus. ${ }^{37}$

A second family of rights is composed of the two environmental rights (EVRs): to a healthy environment and to environmental protection. On the one hand, the rights to a healthy environment and to environmental protection are distinct from other economic and social rights as they relate primarily to the exterior world and can only be provided, or enjoyed, collectively. Unlike other individually-oriented rights, environmental rights are public goods. They nevertheless exhibit a conceptual similarity with other social rights insofar as they have direct impacts on individuals' health and quality of life, and attach to individuals on the basis of their membership in the political community rather than their status as workers.

A third family of social rights includes the rights to Development, Land, Housing, and Food and Water. We identify these as "non-standard social rights" (NSRs) because they are the least likely to be enshrined in constitutions - half of all contemporary constitutions contain no rights of this type - and the least likely to be justiciable. We speculate that the non-standard social rights are distinct from the standard social rights not only because of their relative scarcity, but also because they may be identified as "subsidies.” The so-called Washington Consensus, for example, specifically requires cuts to government spending it identifies as "subsidies," including spending on food, water, housing, electricity, gas, and public transportation. ${ }^{38}$ Housing, food, and water in particular may be plausibly identified as goods that should properly be accessed through the market rather than through state intervention. ${ }^{39}$ A right to land may be perceived as a direct threat to a right to property.

\footnotetext{
${ }^{37}$ John Williamson, What Washington Means by Policy Reform, inLATIN AMERICAN ADJUSTMENT: How MuCH HAS HAPPENED? (John Williamson ed., 1990); William Finnegan, The Economics of Empire: Notes on the Washington Consensus, 306 HARPER's 41-54 (2003); TOKE AIDT \& ZAFIRISTZANNATOS, UniONS AND COLLECTIVE BARGAINING: ECONOMIC EFFECTS IN A GLOBAL ENVIRONMENT (2002), http://go.worldbank.org/YE9DXK2X80.

${ }^{38}$ Williamson, supra note__; Finnegan, supra note

${ }^{39}$ In a comparison of economic and rights-based approaches to social rights, Varun Gauri notes that economists tend to view all ESRs as subsidies. See, Gauri, supra note__. Still, Williamson's template of the Washington Consensus suggests that most international policy-makers distinguish between different types of government spending (Williamson, supra note
} 


\section{LEGAL TRADITIONS}

Contemporary constitutions are drafted in the context of various diffusion processes, including learning, emulation, coercion, and competition. They are influenced by one another. But they are also influenced by national precedents, legal norms and institutions. They may be influenced in particular by legal traditions. In order to investigate the possibility of a relationship between legal traditions and economic and social rights entrenchment, we employed the JuriGlobe classification scheme which identifies four principal legal traditions: civil law, common law, Islamic law, ${ }^{40}$ and traditional or customary law. Using this typology, Perret et al have classified the legal systems of nearly every country in the world. ${ }^{41}$ Unlike the principal alternative classification scheme, ${ }^{42}$ the JuriGlobe scheme's categories are not mutually exclusive; a country's legal system may be classified as containing elements of more than one legal tradition. Qatar, for example, is coded as possessing elements of all four. While the potential for interaction effects may make the identification of interesting and potentially causal relationships between legal tradition and ESR entrenchment more difficult, we employ this system to generate a more nuanced analysis.

\section{A. Civil Law}

The civil law tradition is the most strongly associated with constitutionally entrenched economic and social rights. Of the 193 countries in the dataset classified by the JuriGlobe project, $^{43} 141$ have either a partly or fully civil law tradition. All of the sixteen rights coded in the TIESR dataset are more likely to be both present and justiciable in a civil law country than in a non-civil law country. However, the right to food and water is marginally more likely to be present in jurisdictions without any civil law tradition. Additionally, the right to form and join a trade union approaches the same level of justiciability in countries without a civil law tradition (55\%) as those that are least partly civil law (65\%).

Within this universe, there are some particularly striking differences between the entrenchment of rights in civil and non-civil law countries. The right to strike is present in only $14 \%$ of non-civil law countries but present in $63 \%$ of countries with a civil law tradition. The four Standard Social Rights are each more likely to be both present and justiciable in the constitutions of civil law countries by more than twenty-five percentage points. Civil law countries have an average of 3.4 economic rights per constitution, whereas non-civil law countries have an average of 1.8. Civil law countries have an average of 5.4 constitutionally entrenched social rights, and non-civil law countries average 3.3. The difference in social rights entrenchment is even more

\footnotetext{
40 The JuriGlobe scheme labels legal systems associated with Islam as “Muslim.” In line with contemporary nomenclature, we use "Islamic law" to refer to this category herein.

${ }^{41}$ LOUIS PERRET ET AL., WORLD LEGAL SYSTEMS (2008), http://www.juriglobe.ca/eng/index.php.

42 Rafael La Porta et al., The Quality of Government, 15 J. L. ECON. \& ORG. 222-278 (1999); see, more generally KONRAD ZWEIGERT\& HEIN KÖTZ, 1 INTRODUCTION TO COMPARATIVE LAW (3 ed. 1998).

43 JuriGlobe data is not available for either Kosovo or South Sudan.
} 
pronounced when only justiciable rights are considered: the average non-civil law constitution contains 1.2 justiciable social rights, the average civil law constitution 3.7.

\section{B. Common Law}

There is some tradition of common law in sixty-six countries in the dataset. These countries are predominantly found in the Small Island Developing States, Sub-Saharan Africa, and Asia. The common law tradition is entirely absent from the Postcommunist States and present in only one country in Latin America (Belize). Notwithstanding judicial independence, common law systems are much less likely to have constitutionally entrenched economic and social rights. Constitutions in common law countries have the lowest incidence of environmental rights entrenchment. Only six countries with a common law tradition contain at least one justiciable environmental right: Jamaica, Kenya, Seychelles, South Africa, Uganda, and Yemen. Common law countries also include a comparatively low incidence of economic rights. Setting aside the right to join or form a trade union, which might arguably be considered a civil right, no economic right is present in more than $40 \%$ of constitutions, or justiciable in more than $12 \%$. Countries with a common law tradition also average the fewest number of justiciable rights per constitution with 2.2, and the fewest rights present with 5.2.

\section{Customary Law}

The only country in the dataset governed solely by customary law is Andorra. However, different forms of customary law play a significant role, usually in matters of personal status, in a relatively large number of countries. This is true for example in most African countries, but it is also the case in China and India. ${ }^{44}$ Sixty-five countries include a tradition of customary law, generally mixed with elements of civil and/or common law. Countries that include customary law tend to have marginally fewer rights present than the norm, but approximately one-third fewer justiciable rights than those without a customary law tradition. Countries that include customary law have, on average, a higher number of standard social rights, although the difference is relatively small-3.0 per constitution versus 2.7. Nevertheless, since this legal tradition is, by definition, culturally specific, it is unlikely that any meaningful generalizations can be developed from these associations.

\section{Islamic Law}

The JuriGlobe typology defines Islamic law as "an autonomous legal system which is of a religious nature and predominantly based on the Koran. ${ }^{45}$ Islamic law is often limited to the laws relating to personal status, although personal status may be broadly defined." is present in thirty-eight constitutions in the dataset, but only three-Afghanistan, Maldives, and

\footnotetext{
${ }^{44}$ PERRET ET AL., supra note

45 JuriGlobe refers to "Muslim" law. In this paper we have updated the term in line with contemporary convention.

${ }^{46}$ PERRET ET AL., supra note
} 
Saudi Arabia-have an exclusively Islamic law tradition. Eleven of the sixteen ESRs are less common in countries with an Islamic legal tradition than those with no Islamic legal tradition. The rights to employment derived social security, child protection, and food and water are marginally more common; the right to health is ten percentage points more common. All ESRs are less commonly justiciable in the constitutions of countries with Islamic legal traditions than in those without.

\section{E. Common, Civil, and Mixed Systems}

Because the JuriGlobe classification scheme categorizes countries according to all of their legal traditions, it counts many countries more than once. Our analysis focuses primarily on the differences between common and civil law jurisdictions with respect to economic and social rights guarantees. Therefore we derived a six-fold typology from JuriGlobe data. Countries to which only a single tradition was attributed were coded as "Pure Civil" (77 cases) and "Pure Common" (22 cases). Those that contained one or the other in combination with customary and/or Islamic law were coded as "Mixed Civil" (45 cases) and "Mixed Common" (24 cases) Countries with both civil and common law traditions, solely or in combination with Islamic and/or customary law were classified as "Civil \& Common" (20 cases). ${ }^{47}$

Constitutions in pure common law systems have significantly fewer economic and social rights than constitutions in any other system (Table 3).The average common law constitution contains only 1.59 ESRs, as compared to 9.94 in the average civil law constitution. No country with a pure common law tradition contains more than six economic and social rights. Only five-Belize (6), Fiji (3), Jamaica (3), Ireland (5), and Palau (5)—contain more than two, and more than a quarter of pure common law countries entrench no ESRs. The Non-Standard Social Rights are completely absent in pure common law systems. By contrast, more than two-thirds of countries with pure civil law traditions contain ten or more ESRs.

Table 3. Mean ESRs Present per Constitution by Legal System

\begin{tabular}{lcccccc}
\hline \hline Rights Type & $\begin{array}{c}\text { Pure } \\
\text { Common }\end{array}$ & $\begin{array}{c}\text { Mixed } \\
\text { Common }\end{array}$ & $\begin{array}{c}\text { Civil \& } \\
\text { Common }\end{array}$ & $\begin{array}{c}\text { Mixed } \\
\text { Civil }\end{array}$ & Pure Civil & Total \\
\hline Economic Rights (6) & 0.86 & 2.50 & 2.00 & 2.82 & 4.04 & 2.96 \\
Social Rights(10) & 0.73 & 4.50 & 3.80 & 5.11 & 5.96 & 4.73 \\
$\quad$ Standard Social Rights (4) & 0.59 & 2.58 & 2.25 & 3.24 & 3.32 & 2.78 \\
$\quad$ Environmental Rights (2) & 0.14 & 0.88 & 0.75 & 1.07 & 1.35 & 1.02 \\
$\quad$ Non-Standard Social Rights (4) & 0.00 & 1.04 & 0.80 & 0.80 & 1.29 & 0.94 \\
\hline Total & 1.59 & 7.00 & 5.80 & 7.93 & 10.00 & 7.69 \\
\hline \hline
\end{tabular}

These trends are even more pronounced with respect to justiciable ESRs: only four constitutions in common law countries contain more than one justiciable ESR—Fiji (3), Jamaica

\footnotetext{
${ }^{47}$ The five countries with no tradition of either civil or common law (Afghanistan, Andorra, Maldives, Saudi Arabia, and the United Arab Emirates) were not included in this table, as averages derived from so few cases are unlikely to provide meaningful information, and may even lead to misleading inferences. Where they appear subsequently, they are coded as "Islamic \& Customary."
} 
(3) Ireland (2), and the Marshall Islands (2). No purely common law country constitution includes a single justiciable non-standard social right and only Jamaica contains a justiciable environmental right. On the other hand, purely civil law countries continue to entrench far more rights than any other legal category, with more than $50 \%$ containing ten or more justiciable rights. However, the number of constitutions that contain non-justiciable rights is also quite high-approximately 20\%. Of the three mixed systems it is the "Mixed Common" that contains the lowest proportion of constitutions with no justiciable rights. This is an odd contrast to the fact that only four constitutions in this category-Kenya (12), Malawi (9), , Nepal (8), Uganda (8)contain more than six justiciable rights.

When legal systems are cross-tabulated with constitutional models (Table 4) several notable patterns are evident. More than half (41/71) of the constitutions in pure civil law countries have only justiciable ESRs. But, when civil law is mixed with Islamic or customary law, that proportion shrinks to about one third (16/42). Islamic countries in particular tend to entrench a fairly wide range of aspirational ESRs. More than two-thirds (15/22) of the countries with pure common law traditions contain fewer than two economic and social rights. The combined civil and common category is relatively evenly divided between the three models (5, 6, and 3), while the Mixed Common category (common and Islamic or customary law) is almost exclusively mixed (15/16).

The rights to a fair wage, leisure, employment derived social security, and to strike are much more commonly entrenched in pure civil law countries than in any other system (Figure 1). Of these rights, all but the right to a healthy work environment are present in more than fifty countries with a pure civil law tradition. Conversely, in pure common law constitutions the right to a fair wage is present only in Ireland, the right to employment derived social security is present only in Belize, and the right to a healthy work environment is present in the constitutions of Belize, Fiji, and Ireland. While the right to join or form a trade union is present in nearly twothirds (14) of common law only constitutions, the rights to strike and to leisure are present in none.

Table 4. Constitutional “Models” by Legal System

\begin{tabular}{lccccc}
\hline \hline & Justiciable & Mixed & Aspirational & $\mathrm{N}^{*}$ & $<2$ ESRs \\
\hline Common Only & 3 & 3 & 1 & 7 & 15 \\
Mixed Common & 1 & 15 & 1 & 17 & 7 \\
Civil \& Common & 5 & 6 & 3 & 14 & 6 \\
Mixed Civil & 17 & 13 & 12 & 42 & 3 \\
Civil Only & 41 & 20 & 10 & 71 & 6 \\
Islamic \& Customary & 0 & 2 & 3 & 5 & 0 \\
\hline Total & 67 & 59 & 30 & 156 & 37 \\
\hline * This reflects the number of constitutions in each category that contain more than two economic and \\
social rights. The 37 constitutions that contain zero or one right cannot be classified according to this \\
schema because they can be considered neither mixed nor pure. The number of constitutions with fewer \\
than two economic and social rights is indicated in “<2ESRs".
\end{tabular}


Figure 1. Presence of Economic \& Social Rights

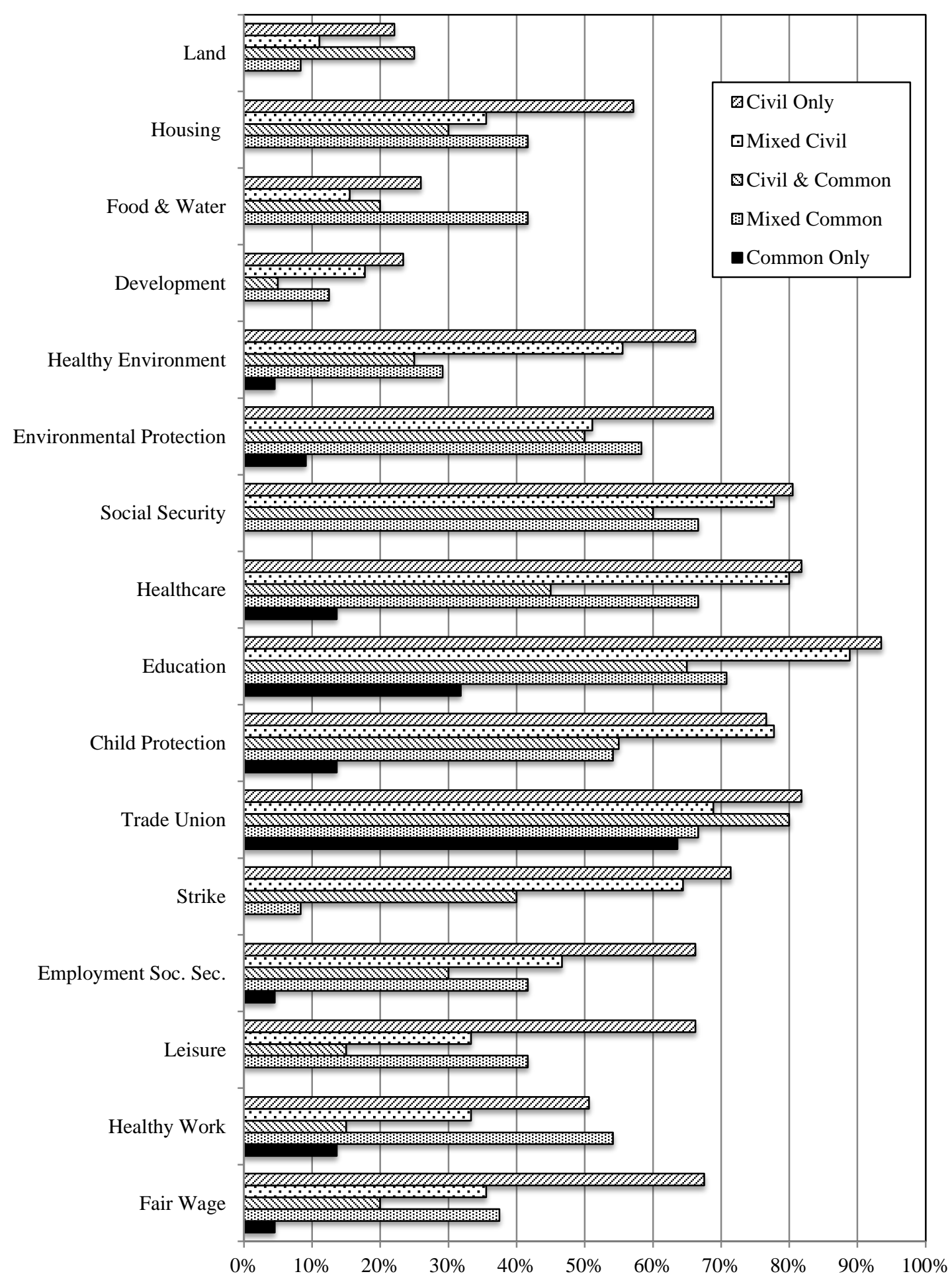

With the exception of the right to social security, which is slightly more common in civil law only constitutions, civil law only and mixed constitutions without a common law tradition contain roughly equal_and high_-proportions of the standard social rights (Figure 1). The two remaining mixed categories include relatively lower proportions of these rights, but almost all of 
them are more likely than not to be present. However, the constitutions of countries with common law only legal traditions entrench remarkably few of the standard social rights. The right to education is present in nearly one third of common law constitutions, but the rights to healthcare and child protection are present in only three, and the right to social security is completely absent.

As with the previous two families of rights, the patterns of particular rights presence demonstrate that jurisdictions with pure civil law traditions tend to have the highest proportions of both environmental rights and non-standard social rights, while common law only constitutions contain the lowest proportion, generally by a wide margin (Figure 1). In fact, none of the non-standard social rights are present in any common law only constitution. The right to environmental protection is present only in Belize and Palau and the right to a healthy environment only in Jamaica. With the exception of common law only jurisdictions, the former is present in half or more of constitutions in each legal system.

When only justiciable rights are considered in relation to legal tradition, similar patterns are evident with a few notable exceptions. The proportion of constitutions containing economic rights drops ten to twenty percentage points in each of the systems with any element of a civil law tradition, although the drops tend to be more pronounced in mixed systems. Those constitutions contain $10-20 \%$ aspirational economic rights. The percentage point shifts are greater when standard social rights and environmental rights are considered, and somewhat smaller when non-standard social rights are considered.

In common law only jurisdictions, the decline is much less pronounced and often nonexistent. The reason for this, however, is quite obvious: only the right to join or form a trade union is present in more than $15 \%$ of these constitutions to begin with. This pattern and explanation hold true for all of the varieties of social rights in common law only constitutions as well, where only the right to education is present in more than $15 \%$ of constitutions. In mixed common law systems all sixteen constitutions containing the right to unionize and the two containing the right to strike do so justiciably. However, the other for economic rights drop twenty-five or more percentage points, meaning they are substantially more likely to be aspirational than justiciable in constitutions of this type. This pattern is also evident in the entrenchment of social rights where only the rights to child protection and education are more likely than not to be justiciable when constitutionally present. In mixed systems containing both civil and common law, ten of sixteen ESRs are more likely to be aspirational than justiciable when present, but the differences are far less pronounced.

\section{F. Legal Origins, Political Culture and the Role of the State}

The field of law and economics has been particularly preoccupied in the last fifteen years or so with the effect of legal origins on economic performance. Beginning with the seminal work of Rafael La Porta and others (LLSV), ${ }^{48}$ scholarship in this vein has sought to explain the differential impact of common law and civil law systems on such legal institutions as investor

\footnotetext{
${ }^{48}$ Rafael La Porta et al., Law and Finance, 106 J. PoLIT. ECon.1113-1155 (1998); La Porta et al., supra note__.
} 
and creditor protection or labour regulation and, by extension, on economic growth. The basic premise of the theory is that "When common and civil law were transplanted into much of the world through conquest and colonization, the rules, but also human capital and legal ideologies, were transplanted as well. Despite much local legal evolution, the fundamental strategies and assumptions of each legal system survived and have continued to exert substantial influence on economic outcomes."49

Scholars differ in their estimation of the relative importance of particular institutional manifestations of legal traditions, and there is a strong counter-argument, at least with respect to economic performance, that the legal tradition of the colonizer is relatively unimportant. ${ }^{50}$ Additionally, the relevance of the common-civil divide has been challenged on the basis of substantial in-group variation and/or a functional, if not formal, convergence of the two. ${ }^{51}$ Nevertheless, this field of inquiry provides an interesting point of departure in seeking to explain the clear differences between these two systems vis-à-vis the entrenchments of ESRs. The clear distinction in terms of ESR uptake suggests the continued utility of the distinction, at least in some respects.

In broad terms, common law systems have been associated with pro-market, minimalstate ideals in which the appropriate role of the law and its instruments is the protection of property rights, the enforcement of contracts, and the defence of individual liberties (i.e. negative rights) against incursion by the state. ${ }^{52}$ These goals are facilitated by an independent judiciary with the ability to countermand legislative or executive action. ${ }^{53}$ Civil law systems have been associated with state intervention through market regulation and social spending. ${ }^{54}$

\footnotetext{
49 Rafael La Porta, Florencio Lopez-de-Silanes \& Andrei Shleifer, The Economic Consequences of Legal Origins, 46 J. ECON. LIT. 285-332, 286 (2008).

${ }^{50}$ Daron Acemoglu, Simon Johnson \& James A Robinson, The Colonial Origins of Comparative Development: An Empirical Investigation, 91 AM. ECON. REV. 1369-1401 (2001); Daron Acemoglu, Simon Johnson \& James A Robinson, The Colonial Origins of Comparative Development: An Empirical Investigation: Reply, 102 AM. ECON. REV. 3077-3110 (2012); c.f. David Y Albouy, The Colonial Origins of Comparative Development: An Empirical Investigation: Comment, 102 AM. ECON. REV. 3059-3076 (2012).

${ }^{51}$ See, e.g. Guangdong Xu, The Role of Law in Economic Growth: A Literature Review, 25 J. ECON. SURVEYS 833871, 848 (2011); Nuno M. GAROuPA\& MARIANA PARgENDlER, A LAW AND ECONOMICS PERSPECTIVE ON LEGAL FAMILIES (2012), http://papers.ssrn.com/sol3/papers.cfm?abstract_id=2104443 (last visited Nov 7, 2012).

52 See, e.g. F. A. Hayek, Freedom, Reason and, Tradition, in THE CONSTITUTION OF LIBERTY 54-70 (1960); CARMine GUERRIERO, LEGAL TRADITIONS AND ECONOMIC PERFORMANCES: THEORY AND EVIDENCE (2010), http://papers.ssrn.com/sol3/papers.cfm?abstract_id=1703467 (last visited Oct 25, 2012). Although the categorical distinction between negative and positive rights has, arguably, been shown to be false (see, e.g. STEPHEN HOLMES \& CASS R. Sunstein, The COST Of Rights: Why LIBERTY DEPENDS ON TAXES (1999).), the distinction remains a valid one insofar as it retains a popular and or partisan political currency.

53 Daniel Klerman \& Paul G Mahoney, Legal Origin?, 35 J. CoMP. ECON. 278-293, 286 (2007); and, for different reasons, Edward L Glaeser \& Andrei Shleifer, Legal Origins, 117 Q. J. ECON. 1193-1229, 1200 (2002).

${ }^{54}$ La Porta, Lopez-de-Silanes, and Shleifer, supra note at 310 .
} 
Table 5. Proportion of ESRs that are Justiciable

\begin{tabular}{lcccccc}
\hline \multirow{2}{*}{ Rights Type } & $\begin{array}{c}\text { Pure } \\
\text { Common }\end{array}$ & $\begin{array}{c}\text { Mixed } \\
\text { Common }\end{array}$ & $\begin{array}{c}\text { Civil \& } \\
\text { Common }\end{array}$ & $\begin{array}{c}\text { Mixed } \\
\text { Civil }\end{array}$ & $\begin{array}{c}\text { Pure } \\
\text { Civil }\end{array}$ & \multirow{2}{*}{ Total } \\
\hline Economic Rights & $68 \%$ & $53 \%$ & $70 \%$ & $63 \%$ & $86 \%$ & $75 \%$ \\
Social Rights & $44 \%$ & $32 \%$ & $49 \%$ & $58 \%$ & $78 \%$ & $64 \%$ \\
$\quad$ Standard Social Rights & $46 \%$ & $42 \%$ & $53 \%$ & $59 \%$ & $79 \%$ & $66 \%$ \\
$\quad$ Environmental Rights & $33 \%$ & $14 \%$ & $40 \%$ & $56 \%$ & $78 \%$ & $62 \%$ \\
$\quad$ Non-Standard Social Rights & $-^{*}$ & $24 \%$ & $44 \%$ & $56 \%$ & $75 \%$ & $61 \%$ \\
\hline Total & $57 \%$ & $40 \%$ & $56 \%$ & $60 \%$ & $81 \%$ & $69 \%$ \\
\hline \hline
\end{tabular}

*There are no non-standard social rights in any solely common law constitutions

This picture of civil law systems, coupled with the civil law commitment to legislative supremacy, might reasonably be expected to generate constitutional entrenchment of high numbers of rights that are aspirational only. A second related hypothesis would be that the tendency of common law countries to be more concerned with protection against incursion from the state, coupled with greater judicial independence, would be expected to generate a lower number of constitutionally entrenched ESRs, but a greater incidence of justiciability. The evidence does not support this pattern. Instead, not only do civil law countries' constitutions contain more ESRs than those of common law countries in each rights family, but those ESRs are also more likely to be justiciable (Table 5). ${ }^{55}$

Several factors point to a broad culturally infused divergence between civil and common law systems manifest not only in law (although certainly there) but also in certain internalized normative beliefs in the appropriateness of certain roles and responsibilities for individuals and for the state. ${ }^{56}$ Birnbaum argues, for instance, that British and U.S. legal cultures seek merely a resolution to the particular problem at hand, whereas the French approach is to seek a universal, logically coherent solution to the problems of all. Civil law reasoning also comprehends an intrinsic connection between liberty and equality. ${ }^{57}$ These positions present an image of France, and of civil law systems more generally, as concerned with structural issues, theoretical coherence, and a balanced notion of liberty and equality in which liberty is the prior condition, but must be checked to protect equality. This, in turn, suggests an active state that would tend to downplay the strong distinction often drawn between negative and positive rights.

Hayek's notion of the differences between common and civil law also foreshadowed this line of reasoning. The key difference between the two, he argued, lies in their distinct conceptions of freedom. A common law conception of freedom values spontaneity and the absence of coercion most highly, whereas a civil law conception sees freedom as the pursuit and attainment of an absolute social purpose. ${ }^{58}$ The former, he contended, supports organic, slow,

\footnotetext{
${ }^{55}$ It should be noted, however, that this pattern is somewhat attenuated when only economic rights are considered.

${ }^{56}$ With regard to "logics of appropriateness" and the theoretical framework from which it is derived (sociological institutionalism), see: JAMES G. MARCH \& JOHAN P. OlSEN, THE LOGIC OF APPROPRIATENESS (2004).

${ }^{57}$ Pierre Birnbaum, The Idea of France 19 (M. B. Debevoisetran., 1st ed. 2001).

${ }^{58}$ Hayek, supra note
} 
self-conscious growth from the bottom-up, whereas the latter argues for doctrinaire deliberateness from the top-down. More recently, Djankov et al. have suggested that all legal systems seek to address two problems: disorder and dictatorship. ${ }^{59}$ There are, they argue, inherent trade-offs between the two, and the balance will be determined by which problem a given jurisdiction is more concerned with. A civil law system is relatively more concerned with preventing or mitigating disorder, whereas common law is concerned with dictatorship and the protection of individuals from state abuse.

This view of the two systems is also borne out empirically. Law and Versteeg classify constitutions as libertarian or statist depending on how many rights they entrench and their "underlying ideology" ${ }^{60}$ The constitutions they identify as "libertarian" have a strong independent judiciary charged with protecting individuals from the state. The state is viewed as a threat to liberty, and rights guarantees are primarily concerned with the protection of the private sphere. In practice, they find, these types of constitutions are associated with the common law tradition and democracy. "Statist" constitutions, on the other hand, envision a large and active role for the state that includes securing the well-being of citizens through the positive obligations of the state. In general they associate these constitutions with the civil law tradition and autocracy. $^{61}$

The "varieties of capitalism" 62 classifications of liberal and coordinated market economies also show preliminary evidence of mapping on to the common-civil law divide. ${ }^{63}$ of the initial sixteen countries studied, all six of the liberal market economies are common law countries. Conversely, the coordinated market economies-characterized by much more state involvement in the economy, intra-sector collaboration, and labour-state-capital corporatist-style arrangements, were all civil law countries. Pontusson's general findings of a liberal America and a social Europe, ${ }^{64}$ as well as much of the political economy literature on welfare states, also point, prima facie, to alignment along these lines. ${ }^{65}$ At the same time, the findings raise

\footnotetext{
${ }^{59}$ The New Comparative Economics, 31 J. Comp. Econ.595-619 (2003).
}

60 Law and Versteeg, supra note__ at 1228-33. Law and Versteeg's methodology nevertheless appears tautological. They classify constitutions according to standards internal to the constitutions themselves (the number of rights they entrench and their "underlying ideological character") and then proclaim that " $90 \%$ of all variation can be explained as a function of just these two variables." What is surprising, given that these so-called variables are features drawn from the constitutions themselves, is that they don't account for $100 \%$ of the variation.

${ }^{61}$ Id. at 1229 .

${ }^{62}$ Peter A. Hall \& Daniel W. Gingerich, Varieties of Capitalism and Institutional Complementarities in the Political Economy: An Empirical Analysis, 39 Brit. J. Polit. SCI. 449-482 (2009); VARIETIES OF CAPITAliSM: The Institutional Foundations of Comparative Advantage, (Peter A. Hall \& David Soskice eds., 2001).

63 Katharina Pistor, Legal Ground Rules in Coordinated and Liberal Market Economies, inCORPORATE Governance in CONTEXT: Corporations, States, AND MARKets in EuRope, JAPAN, AND THE US 249-280 (Klaus J Hopt et al. eds., 2006).

${ }^{64}$ JoNAS PONTUSSON, INEQUALITY AND PROSPERITY: SOCIAL EUROPE Vs. LIBERAL AMERICA (2005).

${ }^{65}$ E.g. Alexander Hicks \&GostaEsping-Andersen, Comparative and Historical Studies of Public Policy and the Welfare State, inA HandBooK of Political Sociology: States, Civil Societies, AND Globalization 509-525 (Thomas Janoski ed., 2005). 
interesting questions with respect to the sources of generous ESR protection in the Nordic countries, all of which are civil law countries that have been characterized as featuring strong "corporatist" labor relation systems and generous welfare state practices throughout much of the last century while being agnostic at best towards extravagant constitutionalism (including ESRs) and judicial review of primary legislation. ${ }^{66}$

Overall, the empirical difference we note between the constitutional entrenchment of economic and social rights in common and civil law countries is supported by a wide range of theories that explain differences between those traditions. Interestingly, our finding that threequarters of pure civil law constitutions justiciably entrench ESRs provides a framework for follow-up research on patterns of ESR adjudication in pure civil law polities. In the conventional portrayal of civil law systems, judges are effectively bureaucrats and administrators with no strong independent authority. Although the idea of the judiciary as a "negative legislator" has been advocated since at least Kelsen, ${ }^{67}$ it has not gone so far as to suggest that a specialized court, let alone regular courts, ought to replace the legislature's interpretation of its duties with that of its own. It remains to be examined whether in the context of ESRs, civil law judges are indeed following their supposed role as implementers and enforcers of the law, rather than "legislators in robes" as the conventional image of their common law counterparts suggests.

\section{REGIONAL VARIATION}

Most, if not all, large-n analyses of constitutions disaggregate data by geographic region, without any strong plausible theoretical account for regional variation. Conceptually, the justification for disaggregating cases on the basis of geographic proximity should rest on a hypothesis that these jurisdictions share particular macro-level traits that have played a role in their respective legal-political development. Employing region as a variable that may have an independent effect on the constitutional status of ESRs relies on demonstrating (or at least plausibly theorizing) that "there are distinctive features of constitutional development in a region.”68 These traits may relate to cultural heritage, religious values, historical experiences, environmental characteristics, a shared sense of supranational identity, or a tendency to copy a regionally influential model.

\footnotetext{
${ }^{66}$ See Ran Hirschl, The Nordic Counter-Narrative: Democracy, Development and Judicial Review, 9 I-CON INT’L J. CONST. L. 449-469 (2011).

${ }^{67}$ Hans Kelsen, Judicial Review of Legislation: A Comparative Study of the Austrian and the American Constitution, 4 J. Polit. 183-200 (1942); Alec Stone, Why Europe Rejected American Judicial Review: And Why it May Not Matter, 101 MicH. L. REV. 2744-2780 (2003).

${ }^{68}$ Vicki C. Jackson, Comparative Constitutional Law: Methodologies, inTHE OXFORD HANDBOOK OF COMPARATIVE Constitutional Law 54-74, 56 (Michel Rosenfeld \&Andras Sajo eds., 2012).
} 
Figure 2. Economic and Social Rights Presence by Region

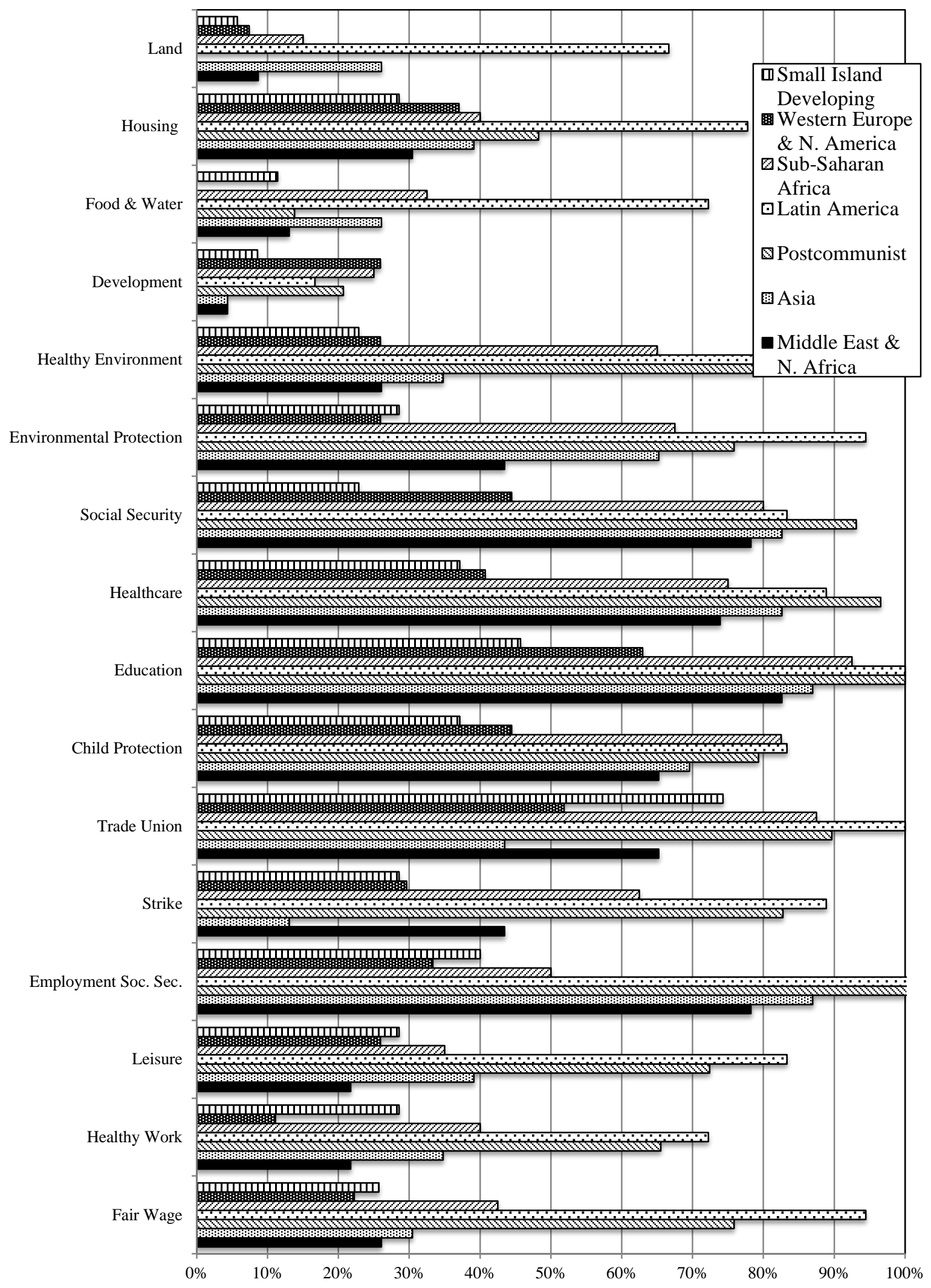


In constructing regional categories, we have relied on existing focus regions based on the United Nations Statistics Division's classifications, ${ }^{69}$ as well as our own best judgment regarding appropriate modifications. Where constitutions appear to reflect a regionally specific norm, we attempt to explore potential explanations for those effects. We find that, with respect to ESR incorporation, some commonly aggregated countries are "regions," in the sense of having a similar or common model of ESR incorporation, and some are not. Specifically, Latin America and the Postcommunist States have strong regional models of economic and social rights entrenchment. Western Europe and North America is categorized by the UN and others as a region for various reasons of historical affinity. Our data show that it may also be treated as a "region" in the sense that its countries share a strong norm against ESR entrenchment. The Middle East and North Africa region has a weak norm (with some notable exceptions) of fairly broad entrenchment of aspirational rights with few justiciable rights. The Small Island Developing States has a weak norm of non-entrenchment, and Sub-Saharan Africa and Asia cannot be considered "regions" at all from the perspective of ESR entrenchment.

\section{A. The Middle East and North Africa}

This region includes twenty-three constitutions. The earliest of these-Lebanon's-was promulgated in 1926, and thirteen were drafted after 1990. Three of these, those of Egypt (2012), Libya (2011), and Morocco (2011), might reasonably be described as emerging from the Arab Spring. Only one constitution currently in force-Iran's - was drafted during the "third-wave" of democratization between 1974 and $1991 .^{70}$ Twenty-one countries in this region have at least some element of Islamic law. ${ }^{71}$ Cyprus has a mixed civil and common law tradition and Turkey is a pure civil law system. ${ }^{72}$ Fifteen other Middle East and North African countries include elements of civil law; one has a tradition of common law, and four have both common and civil law traditions. The United Arab Emirates includes both Islamic and Customary law, and Saudi Arabia is an Islamic mono-system.

Justiciable rights are even more notably absent in this region (Figure 3). Eleven of the twenty-three constitutions in the region contain no justiciable economic and social rights. ${ }^{73}$ Only the constitutions of Turkey and Egypt (both with fourteen) contain more than eight justiciable rights. Only the right to education is justiciable in more than two-fifths of constitutions in the region, while nine rights are justiciable in three or fewer constitutions. This region's constitutions contain an average of 1.4 justiciable economic rights and 2.0 justiciable social rights, well below the global average.

\footnotetext{
69 United NATiOns Statistics Division, StAndARd COUNTRY AND AREA Codes ClassifiCATIONS (2011), http://unstats.un.org/unsd/methods/m49/m49regin.htm (last visited Jul 28, 2012).

70 Samuel Huntington, The Third Wave: Democratization In the LATE Twentieth Century (1991); Tom Ginsburg, The Global Spread of Constitutional Review, inTHE OXFORD HANDBOOK OF LAW AND POLITICS 81-98 (Keith E. Whittington, R. Daniel Kelemen, \& Gregory A. Caldeira eds., 2008).

${ }^{71}$ For present purposes, "Islamic Law” is defined as “an autonomous legal system which is of a religious nature and predominantly based on the Kor'an. In a number of countries of Islamic tradition, it tends to be limited to the laws relating to personal status, although personal status can be rather broadly defined.” (PERRET ET AL., supra note

72 RAN HiRsCHL, CONSTITUTIONAL THEOCRACY 151-59 (2010).

${ }^{73}$ All but Djibouti, Egypt, Iran, the Palestinian Occupied Territories, Sudan, and Turkey
} 
Figure 3. Rights Presence in the Middle East \& North Africa

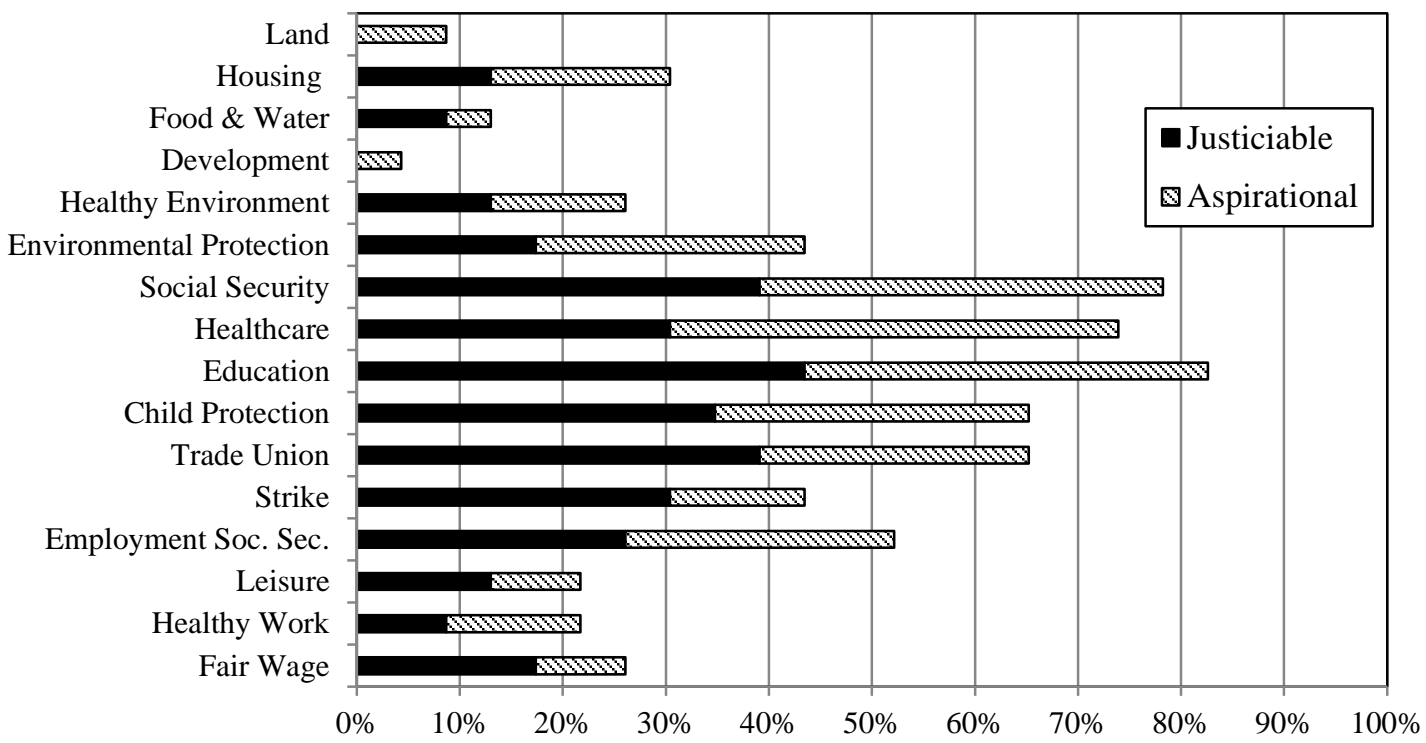

The Middle East and North Africa exhibits a weak regional pattern-it entrenches the standard social rights at roughly the global average, a lower than average incidence of economic rights, and the lowest average number of justiciable rights of any region. The outliers in this region are Turkey and Egypt, with high numbers of justiciable ESRs.

\section{B. Asia}

The Asian region consists of twenty-three constitutions promulgated between 1945 and 2008. There is no regional pattern of ESR entrenchment in Asia, although there may be two subregional norms in South Asia and some East Asian countries, respectively. This absence of a general model supports the argument that there is no uniform "Asian" or "Confucian"74 legal or constitutional tradition. ${ }^{75}$ Nevertheless, a number of countries in South Asia, including Bangladesh, Sri Lanka, Nepal, and Pakistan, appear to have followed the Indian constitutional model of "a fundamental commitment to democracy and norms of equality and non-

\footnotetext{
${ }^{74}$ Tom Ginsburg, Judicial Review in New Democracies: Constitutional Courts in Asian Cases 11-15 (2003).

${ }^{75}$ Cabestan suggests that a number of factors including colonialism, "forced openings," rejection of western domination, and Islam have played important roles in differentially shaping the development of national legal systems in Asia, highlighting at least three major "types" of law in the region: common law; Romano-Germanic law; and, socialist law. (Jean-Pierre Cabestan, Constitutionalism and Western Legal Traditions in Human Rights in Asian Legal Systems: With a Special Focuson Chinese Legal Systems, inONE COUnTRY, Two SySTEMS, ThreE LeGAL ORDERS: PERSPECTIVES OF EVOLUTION (Jorge Costa Oliveira \& Paulo Cardinal eds., 2009), http://www.springerlink.com/content/n5x006051x71m513/.
} 
discrimination" through the constitutional entrenchment of ESRs, ${ }^{76}$ specifically the identification of a wide range of ESRs as directive principles of state policy (i.e. aspirational rights).

There is also a weak norm among the Asian Tiger and Asian Cub countries, ${ }^{77}$ which tend to include the standard social rights as commonly as the global average, have very few workers' rights, and generally lack the non-standard social rights. The outliers here are Singapore and Malaysia — which have no economic and social rights at all-as well as the Philippines—which enshrines a wide range of justiciable rights. ${ }^{78}$ The region also exhibits a division in terms willingness to adjudicate ESR related issues generally. South Asian countries like Bangladesh and Nepal are more likely to entrench justiciable rights, while the more market-oriented East Asian countries are substantially less likely to identify rights as justiciable.

JuriGlobe identifies four Asian countries as pure civil law systems, with all but one of the remainder-Afghanistan, which has an Islamic law mono-system-as mixed systems, roughly evenly split between civil and common law hybrids. Sri Lanka includes a mix of civil, common and customary law, while the Philippines has a mix of civil and common law tradition.

Figure 4. Rights Presence in Asia

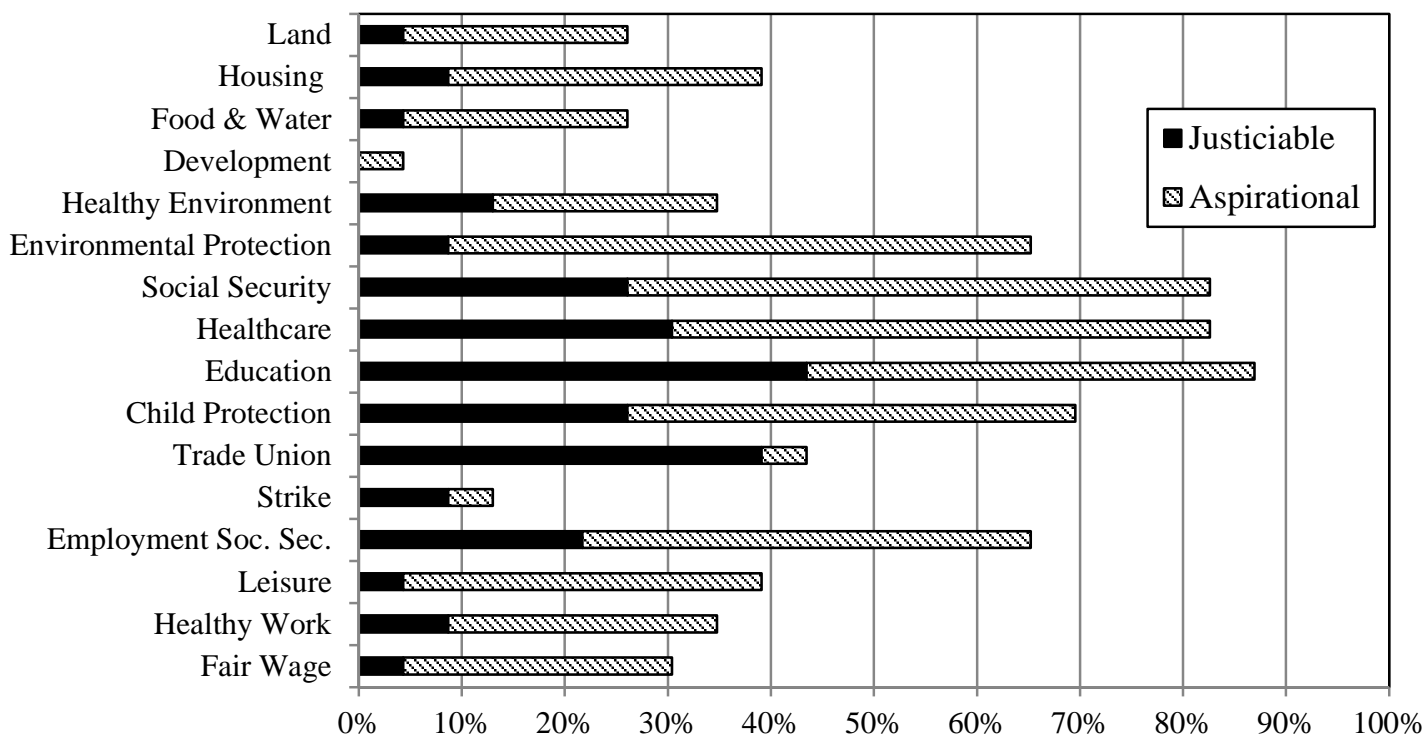

Overall, constitutions in this region are in line with the global average of ESRs present per constitution. The North and South Korean constitutions contain the most rights in the region, with twelve present in each. In line with the global pattern, the four standard social rights—child

\footnotetext{
${ }^{76}$ Byrne and Hossain, supra note__ at 125-26.

${ }^{77}$ Singapore, Taiwan, South Korea, Malaysia, Thailand, Indonesia, and Philippines. Peter L. Berger, An East Asian Development Model?, in In Search of an East Asian Development Model 3-23 (Peter L. Berger \& H. H. Michael Hsiao eds., 1988).

${ }^{78}$ Although the Philippines constitution is often compared to the U.S., with respect to ESR it follows the Latin American model.
} 
protection, education, healthcare, and social security-are the most commonly present, and the second to fifth most commonly justiciable (Figure 4). In fact the average number of SSRs per constitution is about 0.5 higher than the global average of 2.8. But with the exception of a right to employment related social security, each workers' rights is present in less than half of all constitutions in the region. The right to environmental protection is also prevalent in the region, present in two-thirds of constitutions. Asian constitutions average 2.3 ERs per constitution, while the global average is 2.9.

With respect to justiciability, however, the region is substantially below the global average. $^{79}$ Ten countries in the region contain no justiciable ESRs and three-Brunei, Malaysia and Singapore-contain no ESRs of any kind. Only five of the sixteen possible rights are justiciable in more than a quarter of constitutions - the rights to join or form a trade union, child protection, education, healthcare, and social security. None are justiciable in more than half. The right to environmental protection is justiciable only in Thailand and Mongolia and the least common right is development, which is totally absent from the region in justiciable form. Education is the most commonly present ESR and the most commonly justiciable. ${ }^{80}$ The right to join or form a trade union is justiciable in over two-thirds of constitutions. The Constitution of the Philippines contains the greatest number of justiciable ESRs in the region (9).

\section{Postcommunist States}

There are twenty-nine Postcommunist states. Although these countries include different cultures, ethnicities, and nationalisms, they do share a history of rule "by communist parties as parts of imposed systems... enforced models of institutional hardware and ideological software, identities, connections, [and] networks." ${ }^{\text {"1 }}$ This shared experience did not erase cultural and political differences in the region, but the socialist influenced civil law tradition, ${ }^{82}$ geographic contiguity, and near-simultaneity of their independence suggest a strong regional similarity. With the exception of Latvia (1922) the current constitutions of these countries were all drafted after the fall of the Berlin Wall. Those of Serbia (2006), Montenegro (2007), Kosovo (2008) Kyrgyzstan (2010) and Hungary (2012) were drafted in the 2000s.The remaining twenty-three were drafted between 1990 and 1999, predominantly early in the decade.

There appears to be a common, though far from uniform, constitutional approach and model of ESR incorporation in this region. Sadurski argues that the contemporary constitutional model, in particular with respect to ESRs, was driven by two motives that were frequently in tension. Constitution drafters, he argues, were simultaneously influenced by popular expectations

\footnotetext{
${ }^{79}$ With respect to justiciable workers' rights, the global average is 2.2 per constitution while the Asian average is 0.87 . For the standard social rights, the averages are 1.8 and 1.3 respectively.

${ }^{80}$ Education is present in all but three Asian constitutions and justiciable in ten.

${ }^{81}$ M. Krygier\& A. Czarnota, After Postcommunism: The Next Phase, 2 AnN. REV. L. \& SoC. SCI. 299-340, 304 (2006).

${ }^{82}$ La Porta et al., supra note___ PERRET ET AL., supra note___.
} 
regarding the social welfare responsibilities of the state, and by strong external and internal pressure to lay the constitutional groundwork for free-market reform. ${ }^{83}$

Figure 5. Rights Presence in the Postcommunist States

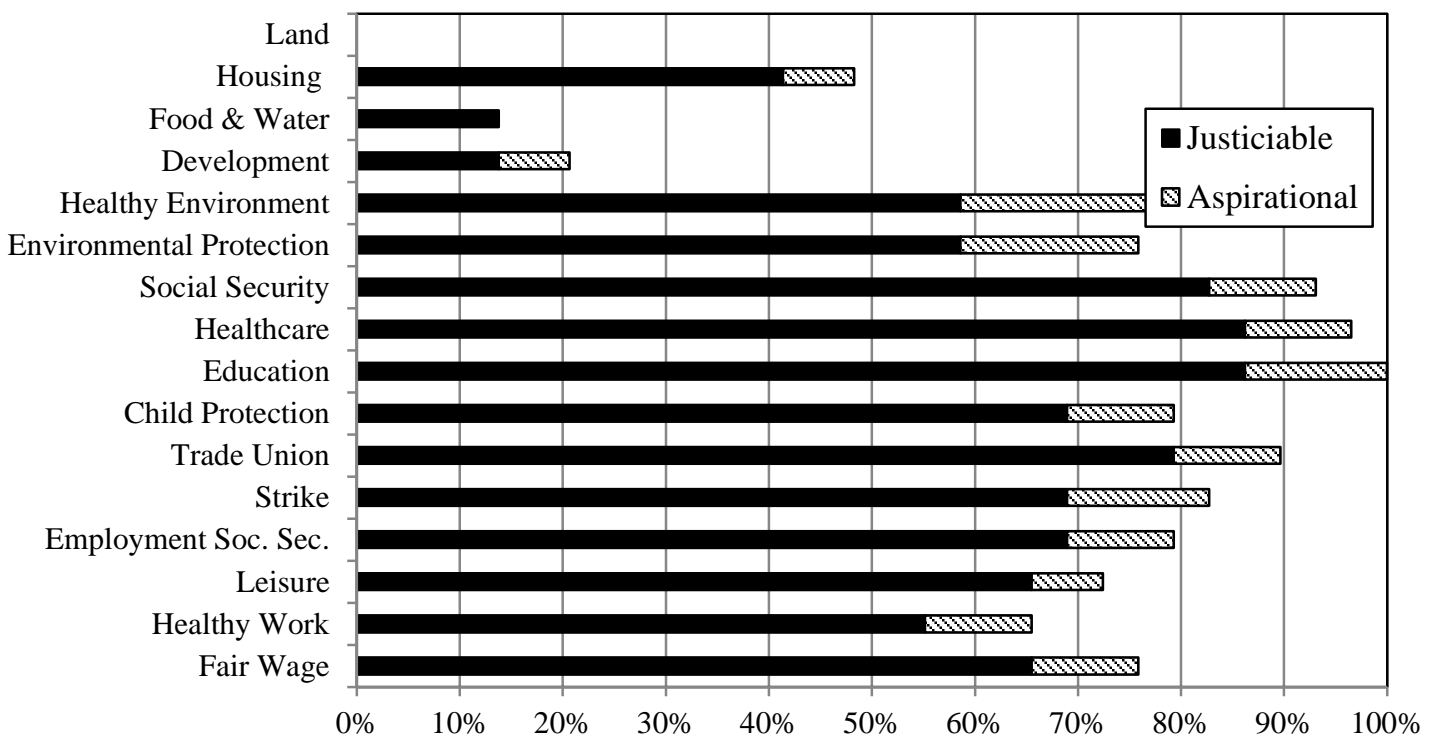

The right to education is present in all constitutions in the region, and the right to healthcare is present in all but Bosnia and Herzegovina, an outlier in the region. In general, constitutions in the region exhibit high levels of ESR presence (Figure 5). For example, all of the workers' rights, standard social rights and environmental rights are present in at least two-thirds of constitutions. On average, the constitutions in this region contain 10.7 ESRs, a higher average than any region but Latin America. The Postcommunist states do have a slightly higher number of standard social rights per constitution-3.7 compared to 3.6 - but are second to Latin America with respect to the presence of workers’ rights, environmental rights, and non-standard social rights.

This region also has the second highest average number of justiciable rights per constitutions, with 9.1. This is a general pattern-the region is second to Latin America in terms of average justiciable rights per constitution in each of the four subgroups of economic and social rights (and only barely so with respect to standard social rights). The rights to education and to health are justiciable in all but four constitutions in the region-Bosnia and Herzegovina, Bulgaria, the Czech Republic, and Slovakia. In fact, in the region it is only these four countries that contain no justiciable rights.

Notwithstanding the general commitment to both ESRs and justiciability, the right to land is completely absent in the Postcommunist States. This surprising absence may reflect strong pressure to reject principles of communist era state-ownership at the time of drafting in the

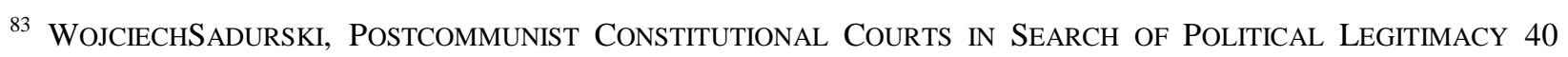
(2001), http://128.252.251.212/harris/conferences/constitutionalconf/Constitutional_Courts_Legitimacy.pdf. 
1990s. The generally large volume and justiciability of all other economic and social rights in these constitutions may be attributed to prior communist experience, particularly as manifest in the strong positive obligations placed on the state. At the same time, every country in this region has a civil law tradition, ${ }^{84}$ which may also have shaped the strong general norm toward ESR incorporation.

\section{Latin America}

The Latin American region includes eighteen countries, and the profile of ESR entrenchment suggests that there is a strong regional model or norm with respect to constitutional ESR entrenchment. This finding confirms a widespread consensus that Latin America has a common and long-standing constitutional and human rights tradition established well before the recent wave of constitution-making, in particular with respect to ESRs and the provision for amparo. ${ }^{85}$ The Mexican constitution of 1916 was (arguably) the first constitution in the world to enshrine economic and social rights, and its early commitment to ESRs is generally considered to have been influential throughout Latin America. The presence throughout the region of amparo or tutela provisions, which allow citizens to bring claims against the state for failure to meet ESR obligations at the trial level, is a key manifestation of this commitment, and an indicator of a common understanding of the role of the state and the courts vis-à-vis the state. ${ }^{86}$

The earliest constitution still in force in the region is that of Mexico (1916) which, along with those of Costa Rica (1949), Uruguay (1966) and Panama (1972), makes up the four constitutions in the region drafted before 1974. Only two-Ecuador (2008) and Bolivia (2009)_ were promulgated in the 2000s. Nevertheless, every constitution in the region has been amended at least once since 1992, half since 2010. JuriGlobe identifies every legal system in the region, except that of Belize (identified as a pure common law system), as pure civil law. ${ }^{87}$

Rights to form or join a trade union and to education are present in all of the region's constitutions. The right to a fair wage is present in all but Belize. Five of the six workers' rights-fair wage, rest and leisure, employment derived social security, strike, and trade unions - are present in more than $80 \%$ of constitutions in the region (Figure 6). The region also contains the highest levels of non-standard social rights. The exception is the right to development which is more commonly present in the Postcommunist States, Sub-Saharan Africa, and Western Europe and North America. The rights to environmental protection, a healthy environment, food and water, housing, and land are all more common in Latin America than in

\footnotetext{
${ }^{84}$ PerRet ET AL., supra note___. Kosovo is not classified by the JuriGlobe scheme.

${ }^{85}$ See, e.g. Paolo G Carozza, From Conquest to Constitutions: Retrieving a Latin American Tradition of the Idea of

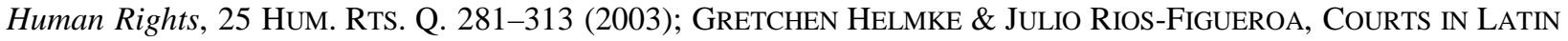
AMERICA (2011); Diego Garcia-Sayan, The Inter-American Court and Constitutionalism in Latin America, 89 TEX. L. REV. 1835 (2010).

${ }^{86}$ For a comprehensive discussion of this concept see: ALLAN R BREWER-CARIAS, CONSTITUTIONAL PROTECTION OF Human Rights in LATin AMERICA: A COMPARATIVE STUDY OF THE AMPARO PROCEEDiNG (2008).

${ }^{87}$ PERRET ET AL., supra note__. This assertion relies on equating French Legal Origin with Civil law systems and UK Legal Origin with Common law systems. La Porta et al., supra note
} 
any other region. The same is true of all other rights except for education, health, and social security-each of which are equally, or marginally more, likely to be justiciable in the Postcommunist States-are more common in Latin America than in any other region. Latin America has the highest average number of economic and social rights present (12.9 per constitution).

Figure 6. Rights Presence in Latin America

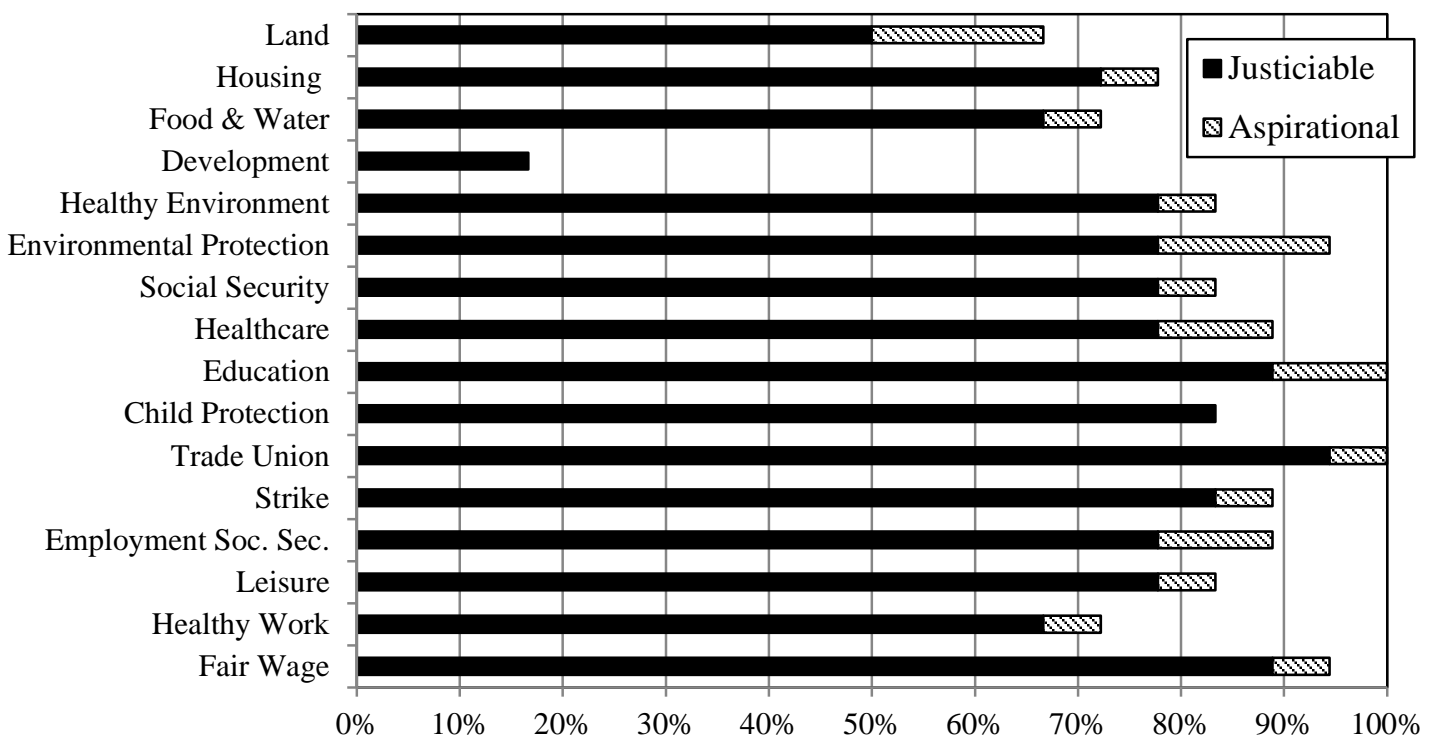

All but the rights to development and land are justiciable in at least two-thirds of the region's constitutions. The right to join or form a trade union is justiciable in all but Colombia. The right to a fair wage is justiciable in all but Belize (absent) and Colombia (aspirational). The right to education is justiciable in all but Chile and Belize. Environmental non-standard social rights - excepting the right to development-are all more commonly justiciable in Latin America than in any other region. The same is true of all other rights except for health and social security, each of which are more likely to be justiciable in the Postcommunist States. The average constitution in the region contains 11.8 justiciable ESRs.

Latin America is distinctive not only for its high overall number of ESRs, but in particular for its comparatively high incidence of workers' and environmental rights. The prevalence of civil law in the region may explain a portion of this prevalence, but it is also likely that some specific regional factors, perhaps relating to a history of populism, the historical strength of trade unions, and the influence of the Mexican constitution, play some role in this as well. As the Middle East and North African region makes apparent, the civil law tradition is not a guarantee of ESR uptake. 


\section{E. Sub-Saharan Africa}

Sub-Saharan Africa is composed of forty countries, and is nearly identical to the UN classification of the same name. ${ }^{88}$ In general these countries have a shared experience of highly extractive colonialism coupled with limited development of physical infrastructure or administrative institutions prior to decolonization. ${ }^{89}$ Sub-Saharan African constitutions are overwhelmingly new, frequently brought about by attempted transitions to democracysuccessful and otherwise. Only two constitutions currently in force were drafted prior to 1974: Botswana (1966) and Cameroon (1972).Four more were promulgated during the "third wave" of democratic transitions: Tanzania (1977); Zimbabwe (1979); Equatorial Guinea (1982) and Liberia (1984). Eighteen were promulgated during the 1990s, and sixteen were drafted after 2000.

\section{Figure 7. Rights Presence in Sub-Saharan Africa}

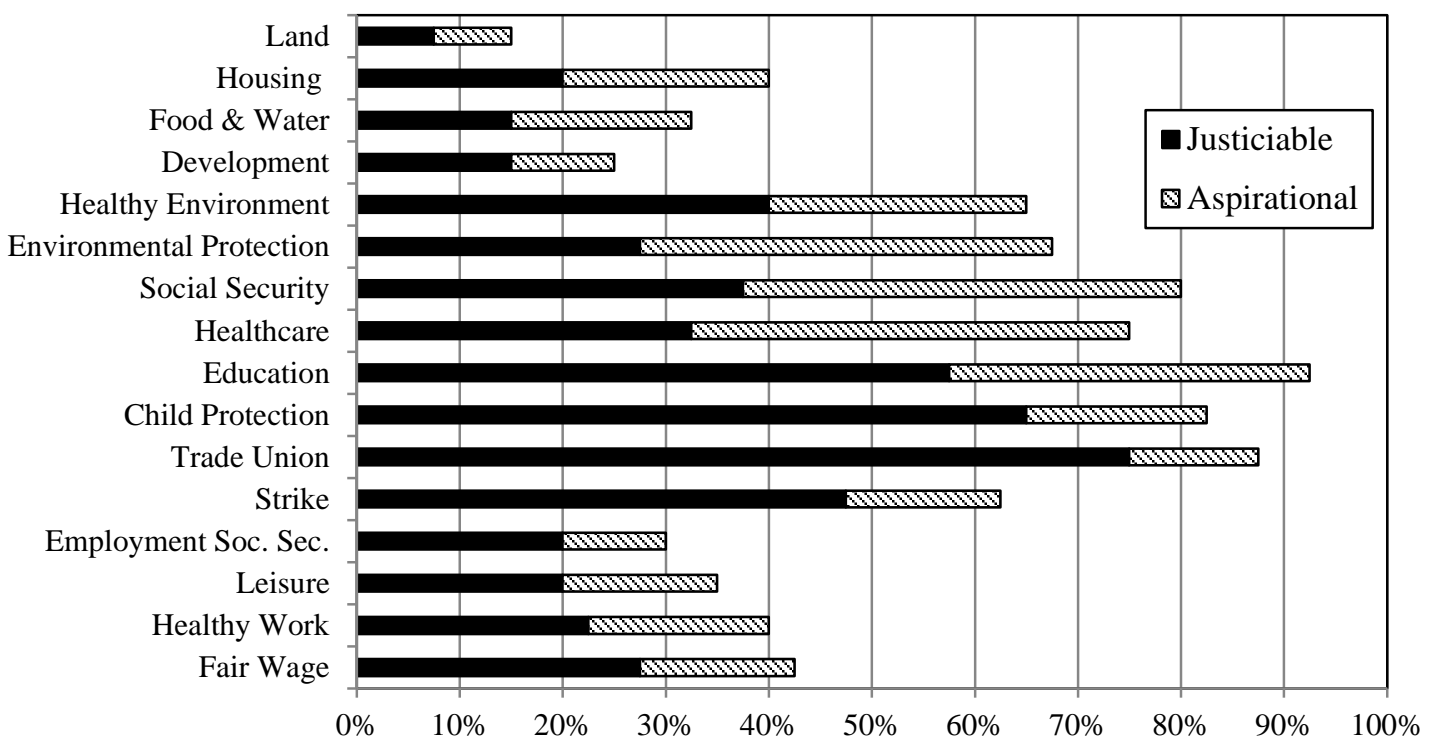

With respect to economic and social rights, Sub-Saharan Africa exhibits almost as much internal variation as the dataset as a whole. There is no apparent Sub-Saharan model or pattern of ESR entrenchment. The region also lacks a common legal tradition. All but three countries have mixed legal traditions, and all but six include customary law. ${ }^{90}$ There are no pure common law systems and only three-Angola, Benin, and the Central African Republic-have pure civil law systems.

\footnotetext{
${ }^{88}$ United NAtions Statistics Division, supra note__. The exceptions being Sudan and Mauritania, which we have included in the Middle East and North Africa category.

${ }^{89}$ See, e.g. Nicolas van de Walle, The Institutional Origins of Inequality in Sub-Saharan Africa, 12 ANN. REV. POLIT. SCI. 307-327 (2009).

${ }^{90}$ PERRET ET AL., supra note
} 
The right to education — absent in Botswana, Côte d'Ivoire, and Zimbabwe-is the most commonly present ESR in the region (Figure 7). With the exception of the rights to strike and to join or form a trade union-which are more common in the region than globally-the incidence of workers' rights in the region is roughly in line with the global average. The non-standard social rights are equally or more likely than average to be present. The average number of standard social rights per constitution is roughly equal to those in Asia in terms of presence (3.3 to 3.2), although the average Sub-Saharan African constitution contains 3.0 workers' rights compared to 2.26 in Asian constitutions. The region has the third highest average number of ESRs per constitution.

In general, justiciable rights are equivalent to the global average. The rights to join or form a trade union and to education are the most commonly justiciable economic and social rights in the region. Unlike with ESR presence, the average number of justiciable standard social rights per constitution is notably higher than in Asia (1.9 to 1.3) and the average Sub-Saharan African constitution contains 2.12 justiciable workers' rights compared 0.9 in Asia. This region has the third highest average number of justiciable ESRs per constitution, although the gap between Latin America and the Postcommunist states, on the one hand, and Sub-Saharan Africa on the other, is substantial-the former average 11.8 and 9.14 rights per constitution respectively, as compared to 5.3 in Sub-Saharan Africa.

\section{F. Western Europe and North America}

Western Europe and North America (WENAM) includes twenty-three countries in Western Europe, as well as Canada, the U.S., Australia, and New Zealand-for a total of twentyseven. Nineteen countries in this region have pure civil law systems, five have pure common law, and two are mixed systems containing both common and civil law-Israel and Malta. The legal system of Andorra is classified as customary law, and in this region only Israel includes Islamic law. $^{91}$

With the notable exception of the right to development-present in $26 \%$ of constitutions in the region, compared with the global average of $16 \%$-Western European and North American constitutions, including those with a civil law tradition, generally have lower than average proportions of every right. The right to food and water is not present in any constitution and only two — education and trade union-are present in more than half (Figure 8). The region also has the lowest average number of workers’ rights present per constitution.

${ }^{91} I d$. 
Figure 8. Rights Presence in Western Europe \& North America

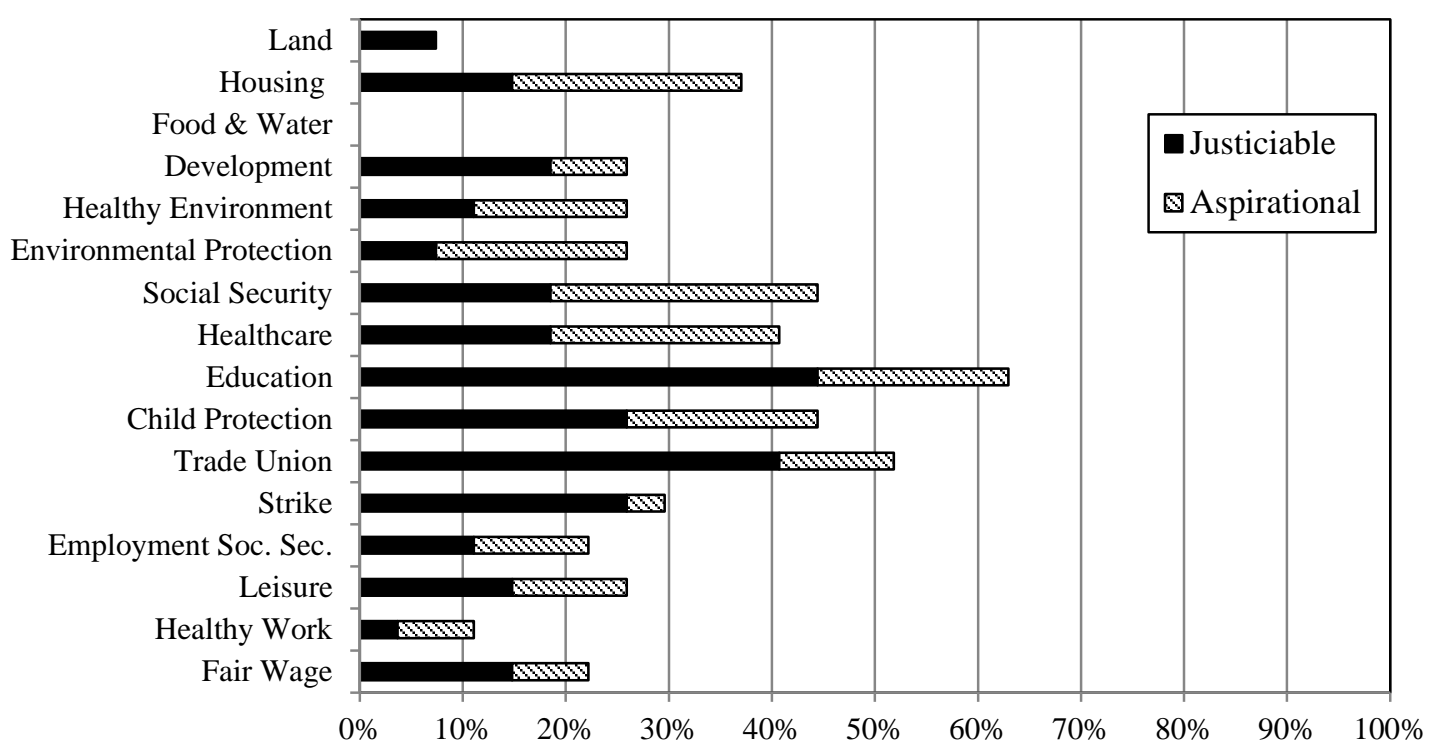

Western Europe and North America nevertheless ranks above Asia in terms of average number of justiciable workers' rights per constitution. More generally, only two rights - to join or form a trade union and education - are justiciable in more than one third of constitutions. The right to development is more commonly justiciable in the region (19\%) than any other. In general, however, the region is remarkable for its low levels of ESR entrenchment. Such rights are relatively less common in constitutions drafted prior to the third wave, as most of these were. These countries also have high levels of economic development and many also have wellestablished social welfare institutions that may make economic and social rights seem redundant.

\section{G. Small Island Developing States (SIDS)}

The Small Island Developing States includes thirty-five countries. This region is identical to the UN statistical division's classification of the same name, with the exception of Belize ${ }^{92}$ More than half of the constitutions in the region were promulgated during the "third-wave" of democratization, and only seven after 1990. This region has five pure civil law jurisdictions, four mixed civil law systems, five mixed systems that contain both civil and common law, four mixed common law systems, sixteen pure common law systems, and one Islamic law system (Maldives).

In general, constitutions in this region exhibit no strong regional model other than a general tendency to include fewer than average ESRs. Only two rights - to join or form a trade union and education-are present in more the $40 \%$ of constitutions in the region (Figure 9). In fact, five of the regions' constitutions-Kiribati, Micronesia, Tonga, Trinidad and Tobago, and

\footnotetext{
${ }^{92}$ Because Belize is not an island, and is territorially contiguous with Latin America, we classified it as part of Latin America.
} 
Vanuatu-contain no ESRs, and another fourteen contain only one. At the same time, however, the constitutions of Sao Tome and Principe and East Timor contain twelve, those of Haiti, Seychelles, and Maldives thirteen, that of Cape Verde fourteen and the Dominican Republic's fifteen.

Figure 9. Rights Presence in Small Island Developing States

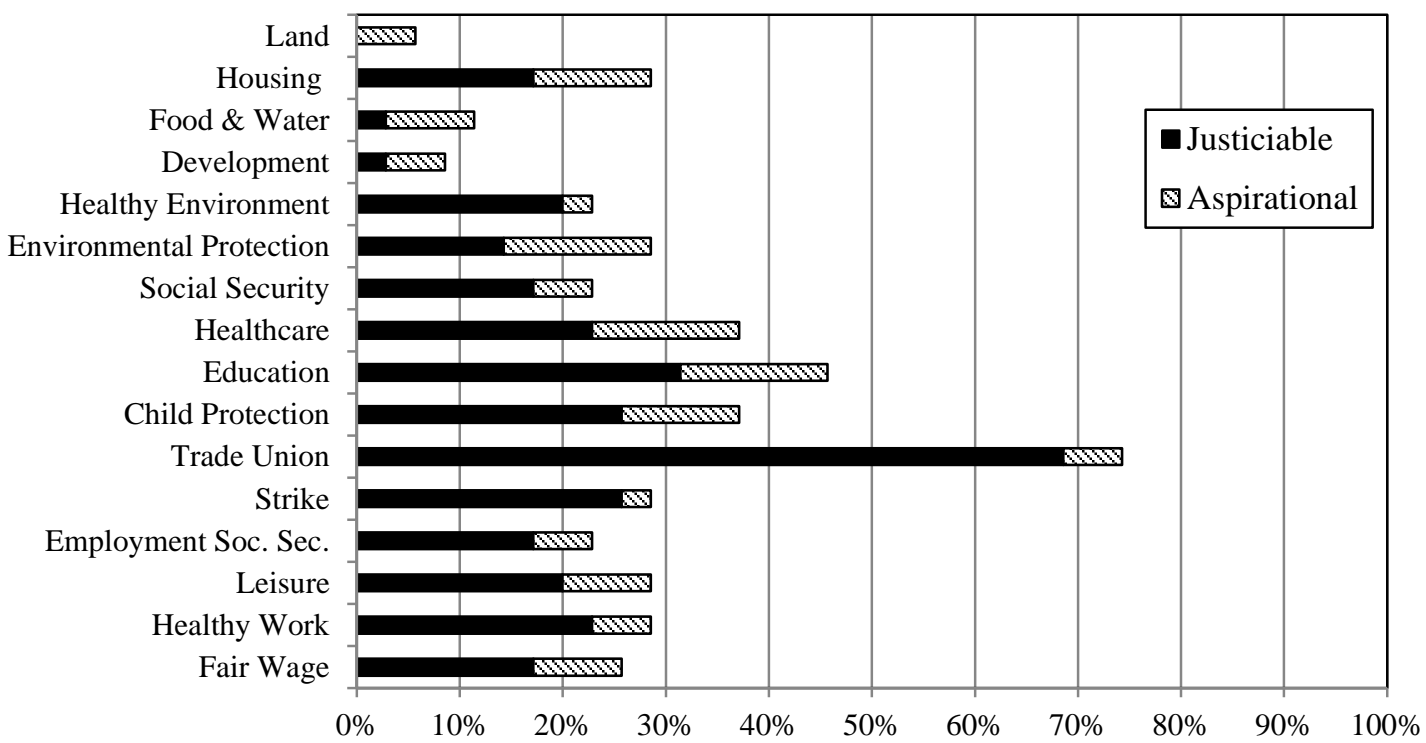

Nine countries in this region contain no justiciable ESRs, and a further fourteen contain only one. Only the right to join or form a trade union is justiciable in more than one third of all constitutions in this region. Six constitutions-Cape Verde (13), the Dominican Republic (13), Seychelles (13), East Timor (12), Haiti (12), and Sao Tome and Principe (11)—contain more than ten justiciable ESRs. This pattern tends to follow legal traditions evident in the previously discussed regions. That is, there appears to be a negative relationship between the common law and ESRs.

The Small Island Developing States do not show a great deal of internal coherence, and might also be characterized as a bifurcated region. Twenty of the thirty-three constitutions in the region contain one or fewer ESRs. The region is also disproportionately common law. However, there are also six constitutions in the region that contain more than ten ESRs, a factor that likely attenuates negative correlations that might otherwise be present in the region.

In conclusion, our analysis of regional ESR entrenchment indicates that some historically identified regions have strong predictive capacity with respect to ESR entrenchment, some have weak predictive capacity, and some have no predictive capacity at all. Two geographic regions, Latin America and the Postcommunist States, exhibit strong regional norms regarding constitutional entrenchment of ESRs. Latin American constitutions entrench the broadest number of rights, and identify most rights as justiciable. Postcommunist constitutions also enshrine a broad range of rights, and also tend to identify ESRs as justiciable, but unlike Latin American 
constitutions they uniformly fail to include a right to land, and are less likely to include the nonstandard social rights. Western Europe and North America and the Small Island Developing States both have a weak regional norm of low numbers of ESRs either present or justiciable. Middle East and North Africa has a weak norm of entrenching an average number of aspirational rights and very few justiciable rights. Sub Saharan Africa and Asia exhibit so much internal variation that we can identify no clear pattern of ESR entrenchment. We suggest that different factors, including diffusion, politics, and timing, explain each of these regional models.

\section{STATISTICAL ANALYSIS}

Our dependent variable is the number of economic and social rights formally entrenched in a constitution. As described above, this variable can be calculated in three ways: the number of aspirational rights, the number of justiciable rights and the number of rights present. In all cases, the variable can take on sixteen possible values_obtained by counting the number of economic and social rights in a particular constitution-all of which are non-negative integers. This suggests that the data be treated as count data and that specific regression techniques adapted for use with non-normally distributed data should be employed. Two principal options for doing so are the Poisson and negative binomial regression models. As there is evidence of overdispersion, we have employed the latter in our analysis. ${ }^{93}$

Our principal variables of interest are legal tradition and region, the characteristics of which are outlined above. ${ }^{94}$ Region is incorporated into the analysis as a set of six dummy variables; the reference category employed throughout is Western Europe and North America. Legal tradition has been operationalized in two ways, resulting in two models for each of rights present, justiciable rights, and aspirational rights. ${ }^{95}$ The first set of models (JG-1/2/3) is based on the pure common law through pure civil law tradition used throughout; the reference group is pure common law. These models also include a dummy variable for Islamic \& Customary law only. Due to the prominence of the five-fold categorization employed by LLSV, ${ }^{96}$ we have also incorporated that classification scheme into a second set of models (LSV-1/2/3), using UK legal

\footnotetext{
${ }^{93}$ A key assumption of the Poisson regression model is equidispersion-the equality of conditional variance and mean. Contrary to this assumption, for each of the three dependent variables, the variance is three to five times larger than the mean and for each model the likelihood-ratio chi-square test rejects the hypothesis that the dispersion parameter alpha is equal to zero with greater than 99.5\% confidence. Valid statistical inference using the Poisson model is possible when this assumption is violated, however, more efficient estimators can be obtained by using alternative approaches and a failure to correct for overdispersion can result in substantially inflated estimates of significance. The standard alternative regression model for count data is negative binomial regression. A. CoLIN Cameron \& Pravin K. Trivedi, Regression Analysis of Count Data 69-70 (2013); see, e.g. Alison F. Del Rossi \& W. Kip Viscusi, The Changing Landscape of Blockbuster Punitive Damages Awards, 12 AM. L. \& Econ. REV. 116-161, 137-38 (2010); Tom S. Clark, The Separation of Powers, Court Curbing, and Judicial Legitimacy, 53 AM. J. POLIT. SCI. 971-989, 980-81 (2009).

${ }^{94}$ See, also, tables A1 and A2, infra.

${ }^{95}$ A third set of models (Non-1/2/3) using the non-exclusive JuriGlobe classification scheme discussed in Part IV (see, generally PERRET ET AL., supra note___.). These results are reported in Tables A3 and A4, infra.

${ }^{96}$ For a concise survey of this material, see La Porta, Lopez-de-Silanes, and Shleifer, supra note
} 
origin as the reference group. Although most regions have a mixture of common, civil, Islamic and customary law, there is a clear relationship between region and legal tradition in Latin America and the Postcommunist States, where all but one country has a civil law tradition. This overlap suggests the possibility of problems associated with collinearity-the correlation of two or more independent variables. Although collinearity is not a threat to overall model fit, it can impair the utility of a model by inflating standard errors and limiting validity of inference about the independent effects of collinear variables. ${ }^{97}$

Further analysis, however, indicates that multicollinearity is not an issue. In every region except Sub-Saharan Africa, countries with solely civil law traditions have a higher average number of ESRs per constitution than those without a civil law tradition (see Table 6). On the other hand, pure civil law jurisdictions in Latin American countries-all of the countries in the region but for Belize-average twice as many ESRs as pure civil law countries in Western Europe and North America. The inter-regional variation associated with legal tradition in the Small Island Developing States is also marked. This suggests that both region and legal tradition matter. More formally, when expanded into dummy variables, none of the Variance Inflation Factors (VIFs) in either the Region/JuriGlobe or Region/LLSV models is greater than 6.4, and most are substantially less. A commonly accepted rule of thumb is that VIFs of less than ten are not problematic. This suggests that multicollinearity is not a serious threat and that region and legal tradition are separable in terms of the measurement of their effects. ${ }^{98}$

Table 6. Average ESRs Present per Constitution

\begin{tabular}{lcccccc}
\hline \hline Region & $\begin{array}{c}\text { Pure } \\
\text { Common }\end{array}$ & $\begin{array}{c}\text { Mixed } \\
\text { Common }\end{array}$ & $\begin{array}{c}\text { Civil \& } \\
\text { Common }\end{array}$ & $\begin{array}{c}\text { Mixed } \\
\text { Civil }\end{array}$ & $\begin{array}{c}\text { Pure } \\
\text { Civil }\end{array}$ & Total $^{\text {b }}$ \\
\hline Middle East \& N. Africa & - & - & $6.50^{\mathrm{a}}$ & 6.27 & - & 6.76 \\
Asia & - & 6.11 & $10.00^{\mathrm{a}}$ & 8.57 & $7.00^{\mathrm{a}}$ & 7.41 \\
Postcommunist & - & - & - & - & 10.82 & 10.82 \\
Latin America & - & - & - & - & 13.35 & 12.94 \\
Sub-Saharan Africa & - & 10.20 & 6.14 & 8.84 & $9.00^{\mathbf{a}}$ & 8.72 \\
Western Europe \& N. America & 1.40 & - & $0.50^{\mathrm{a}}$ & - & 5.79 & 4.54 \\
Small Island Developing & 1.38 & $0.75^{\mathrm{a}}$ & 5.20 & $8.75^{\mathrm{a}}$ & 12.20 & 4.32 \\
\hline Total & 1.59 & 7.00 & 5.80 & 7.93 & 10.00 & 7.69 \\
\hline \hline$-<$ 2 Observations. & & & & & \\
a $<$ 5 Observations. & & & & & \\
b Totals may vary from reported averages as a result of the non-reporting of cells with $<2$ observations.
\end{tabular}

In line with constitutionalism and judicial review more generally, a number of scholars have suggested an expansionist tendency in the scope of rights protected in constitutions. In particular, several investigations have found a positive correlation-sometimes statistically significant, sometimes not-between the newness of a constitution and the number of rights it

\footnotetext{
${ }^{97}$ See, e.g. Carl F. Mela \& Praveen K. Kopalle, The Impact of Collinearity on Regression Analysis: The Asymmetric Effect of Negative and Positive Correlations, 34 APPLIED ECON. 667-677 (2002).

98 Although we do not employ a standard linear regression model in our analysis (e.g. Ordinary Least Squares), because multicollinearity is a quality of the independent variables rather than the regression model, the standard diagnostics are applicable.
} 
contains. 99 Beck et al, for example, find "a tendency for younger regimes and more recently amended constitutions to have more human rights mentions." ${ }^{\prime 00}$ As such, we include both the year in which the current constitution came in to force and the year in which it was most recently amended as a control for time. However, our ability to control for the effects of time is problematic in that the TIESR dataset codes only contemporary constitutions, and not constitutions over time. Specifically, we cannot control for the possibility of constitutions incorporating economic and social rights via amendment, perhaps decades after initial entrenchment. The inability to account for this condition would nevertheless make the hypothesis that economic and social rights entrenchment is becoming more frequent more difficult to prove, as it would not account for modern adoption via amendment in an older constitution. On the other hand, we cannot account for the possibility that earlier constitutions in a jurisdiction may also have included economic and social rights, which would lend artificial weight to the hypothesis. We believe the former possibility is far more likely than the latter, except in Latin America. ${ }^{101}$ This suggests that the bias introduced by employing only cross-sectional data inclines in favour of attenuating the relationship between constitutional newness and ESR entrenchment.

We have also included countries' ICESCR ratification status to account for its potential influence on formal constitutional entrenchment. ${ }^{102}$ The expected direction of that influence, however, is not entirely clear. On the one hand, it may be that countries ratifying the covenant are signalling their concurrence with the basic principles and an intention to protect them. In that case, a positive correlation between ICESCR ratification and ESR entrenchment ought to be evident. On the other hand, ratification could be associated with a lower likelihood of constitutional entrenchment as constitutionalization might be considered redundant. Finally, in line with standard practice, we have also included the natural logarithms of population and GDP per capita as additional control variables. ${ }^{103}$

\footnotetext{
${ }^{99}$ Ben-Bassat and Dahan, supra note___ at 111; Law and Versteeg, supra note__.

${ }^{100}$ Colin J Beck, Gili S Drori \& John W Meyer, World Influences on Human Rights Language in Constitutions: A Cross-National Study, 27 InT’L. Sociol. 483-501, 497 (2012). See also John W. Meyer et al., World Society and the Nation-State, 103 AM. J. SocIOL. 144-181 (1997).

${ }^{101}$ The two dominant influences on Latin American constitutions have been the US Constitution and the 1917 Mexican Constitution. As the latter included ESRs, it is not unreasonable to infer the inclusion of at least limited ESR protections in prior versions of Latin American constitutions.

${ }^{102}$ Ratification status was coded based on Chapter IV(3) International Covenant on Economic, Social and Cultural Rights: Ratification Status, in UNITED NATIONS TREATY COLLECTION (2014).

${ }^{103}$ GDP per capita is measured in constant USD 2005. Both variables were taken from the World Bank's World Development Indicators database: http://data.worldbank.org/data-catalog/world-development-indicators. Due to limited data availability, the inclusion of GDP per capita reduces the number of cases by 16 (from 191 to 175).
} 
Table 7. Negative Binomial Regression Models (Incidence Rate Ratios \& t-Statistics)

\begin{tabular}{|c|c|c|c|c|c|c|}
\hline & \multicolumn{2}{|c|}{ Present } & \multicolumn{2}{|c|}{ Justiciable } & \multicolumn{2}{|c|}{ Aspirational } \\
\hline & JG -1 & LLSV-1 & $\mathrm{JG}-2$ & LLSV-2 & JG-3 & LLSV-3 \\
\hline \multicolumn{7}{|l|}{ JuriGlobe } \\
\hline Mixed Common & $\begin{array}{l}2.761 \\
(4.21)^{* *}\end{array}$ & & $\begin{array}{l}2.032 \\
(1.49)\end{array}$ & & $\begin{array}{l}2.294 \\
(1.09)\end{array}$ & \\
\hline Civil \& Common & $\begin{array}{c}2.793 \\
(4.41)^{* *}\end{array}$ & & $\begin{array}{l}3.133 \\
(2.64)^{* *}\end{array}$ & & $\begin{array}{l}1.564 \\
(0.64)\end{array}$ & \\
\hline Mixed Civil & $\begin{array}{c}3.111 \\
(4.91)^{* *}\end{array}$ & & $\begin{array}{c}3.826 \\
(3.15)^{* *}\end{array}$ & & $\begin{array}{l}1.568 \\
(0.60)\end{array}$ & \\
\hline Pure Civil & $\begin{array}{l}3.698 \\
(5.98) * *\end{array}$ & & $\begin{array}{c}5.183 \\
(3.90)^{* *}\end{array}$ & & $\begin{array}{l}1.352 \\
(0.50)\end{array}$ & \\
\hline Islamic \& Customary & $\begin{array}{c}3.330 \\
(3.97)^{* *}\end{array}$ & & $\begin{array}{l}1.247 \\
(0.32)\end{array}$ & & $\begin{array}{l}3.605 \\
(1.33)\end{array}$ & \\
\hline \multicolumn{7}{|l|}{ LLSV } \\
\hline French Origin & & $\begin{array}{c}1.456 \\
(3.60)^{* *}\end{array}$ & & $\begin{array}{l}2.339 \\
(4.10)^{* *}\end{array}$ & & $\begin{array}{l}0.792 \\
(0.73)\end{array}$ \\
\hline Socialist Origin & & $\begin{array}{l}1.028 \\
(0.13)\end{array}$ & & $\begin{array}{l}1.284 \\
(0.53)\end{array}$ & & $\begin{array}{l}1.239 \\
(0.26)\end{array}$ \\
\hline German Origin & & $\begin{array}{l}1.667 \\
(1.86)\end{array}$ & & $\begin{array}{l}2.205 \\
(1.34)\end{array}$ & & $\begin{array}{l}0.844 \\
(0.20)\end{array}$ \\
\hline Scandinavian Origin & & $\begin{array}{l}1.744 \\
(1.75)\end{array}$ & & $\begin{array}{l}1.041 \\
(0.06)\end{array}$ & & $\begin{array}{l}2.137 \\
(0.81)\end{array}$ \\
\hline \multicolumn{7}{|l|}{ Region } \\
\hline Middle East \& North Africa & $\begin{array}{l}1.091 \\
(0.43)\end{array}$ & $\begin{array}{l}1.161 \\
(0.73)\end{array}$ & $\begin{array}{l}0.875 \\
(0.31)\end{array}$ & $\begin{array}{l}0.724 \\
(0.79)\end{array}$ & $\begin{array}{l}2.099 \\
(0.98)\end{array}$ & $\begin{array}{l}3.254 \\
(1.79)\end{array}$ \\
\hline Asia & $\begin{array}{l}1.254 \\
(1.14)\end{array}$ & $\begin{array}{l}1.563 \\
(2.02)^{*}\end{array}$ & $\begin{array}{l}0.923 \\
(0.18)\end{array}$ & $\begin{array}{l}0.995 \\
(0.01)\end{array}$ & $\begin{array}{l}3.830 \\
(1.72)\end{array}$ & $\begin{array}{l}4.814 \\
(1.96)\end{array}$ \\
\hline Postcommunist States & $\begin{array}{l}1.410 \\
(2.20)^{*}\end{array}$ & $\begin{array}{l}2.264 \\
(3.16)^{* *}\end{array}$ & $\begin{array}{l}1.937 \\
(1.98)^{*}\end{array}$ & $\begin{array}{l}3.386 \\
(2.25)^{*}\end{array}$ & $\begin{array}{l}0.852 \\
(0.28)\end{array}$ & $\begin{array}{l}0.684 \\
(0.38)\end{array}$ \\
\hline Latin America & $\begin{array}{l}1.904 \\
(3.98)^{* * *}\end{array}$ & $\begin{array}{l}2.151 \\
(4.02)^{* *}\end{array}$ & $\begin{array}{l}2.827 \\
(2.97)^{* *}\end{array}$ & $\begin{array}{l}2.768 \\
(2.75)^{* *}\end{array}$ & $\begin{array}{l}1.105 \\
(0.15)\end{array}$ & $\begin{array}{l}1.171 \\
(0.23)\end{array}$ \\
\hline Sub-Saharan Africa & $\begin{array}{l}1.363 \\
(1.47)\end{array}$ & $\begin{array}{l}1.503 \\
(1.84)\end{array}$ & $\begin{array}{l}1.403 \\
(0.76)\end{array}$ & $\begin{array}{l}1.356 \\
(0.71)\end{array}$ & $\begin{array}{l}2.974 \\
(1.24)\end{array}$ & $\begin{array}{l}4.187 \\
(1.72)\end{array}$ \\
\hline Small Island Developing & $\begin{array}{l}1.486 \\
(1.92)\end{array}$ & $\begin{array}{l}1.410 \\
(1.48)\end{array}$ & $\begin{array}{l}2.694 \\
(2.14)^{*}\end{array}$ & $\begin{array}{l}1.878 \\
(1.35)\end{array}$ & $\begin{array}{l}0.868 \\
(0.19)\end{array}$ & $\begin{array}{l}1.169 \\
(0.20)\end{array}$ \\
\hline \multicolumn{7}{|l|}{ Control Variables } \\
\hline ICESCR Ratified & $\begin{array}{l}1.326 \\
(2.10)^{*}\end{array}$ & $\begin{array}{l}1.435 \\
(2.46)^{*}\end{array}$ & $\begin{array}{l}1.367 \\
(1.14)\end{array}$ & $\begin{array}{l}1.353 \\
(1.09)\end{array}$ & $\begin{array}{l}2.429 \\
(1.71)\end{array}$ & $\begin{array}{c}2.729 \\
(2.13)^{*}\end{array}$ \\
\hline Year Last Amended & $\begin{array}{l}1.007 \\
(1.61)\end{array}$ & $\begin{array}{l}1.014 \\
(2.60)^{* *}\end{array}$ & $\begin{array}{l}1.009 \\
(0.92)\end{array}$ & $\begin{array}{l}1.014 \\
(1.40)\end{array}$ & $\begin{array}{l}1.004 \\
(0.25)\end{array}$ & $\begin{array}{l}1.016 \\
(0.98)\end{array}$ \\
\hline Year into Force & $\begin{array}{c}1.010 \\
(4.97)^{* *}\end{array}$ & $\begin{array}{l}1.010 \\
(4.84)^{* *}\end{array}$ & $\begin{array}{l}1.014 \\
(3.49)^{* *}\end{array}$ & $\begin{array}{l}1.014 \\
(3.49)^{* *}\end{array}$ & $\begin{array}{l}1.009 \\
(1.55)\end{array}$ & $\begin{array}{l}1.010 \\
(1.75)\end{array}$ \\
\hline Log GDP per capita (ln) & $\begin{array}{l}1.004 \\
(0.10)\end{array}$ & $\begin{array}{l}0.999 \\
(0.02)\end{array}$ & $\begin{array}{l}0.961 \\
(0.47)\end{array}$ & $\begin{array}{l}0.991 \\
(0.11)\end{array}$ & $\begin{array}{l}1.305 \\
(1.60)\end{array}$ & $\begin{array}{l}1.276 \\
(1.44)\end{array}$ \\
\hline Log Population (ln) & $\begin{array}{c}1.080 \\
(3.04)^{* *}\end{array}$ & $\begin{array}{l}1.102 \\
(3.43)^{* *}\end{array}$ & $\begin{array}{l}1.149 \\
(2.39)^{*}\end{array}$ & $\begin{array}{l}1.156 \\
(2.44)^{*}\end{array}$ & $\begin{array}{l}0.947 \\
(0.58)\end{array}$ & $\begin{array}{l}1.005 \\
(0.05)\end{array}$ \\
\hline Observations & 175 & 173 & 175 & 173 & 175 & 173 \\
\hline Pseudo R-squared & 0.14 & 0.12 & 0.10 & 0.09 & 0.04 & 0.04 \\
\hline
\end{tabular}

Table 7 reports several key findings of our statistical analysis. These tables report Incidence Rate Ratios (IRRs) rather than regression coefficients. This was done to allow a 
clearer, more straightforward interpretation of the results. ${ }^{104}$ In the case of dummy variables, the IRR can be interpreted as the factor by which cases with the characteristic captured by the dummy are predicted to vary from the reference group, all else being equal. ${ }^{105}$ Where the variable has more than two values, multiplying the sum of 1-IRR by 100 gives the predicted percent change in the dependent variable for a one unit increase in the independent variable in question, holding all other variables constant. ${ }^{106}$ Table 7 also reports the pseudo- $\mathrm{R}^{2}$ of each model. ${ }^{107}$ This is a measure of explained variance; however, it cannot be interpreted in the same manner and is not directly comparable with the more familiar $\mathrm{R}^{2}$ of linear regression models such as Ordinary Least Squares.

Surprisingly, there are almost no significant relationships between the independent variables and aspirational rights (JG-3, LLSV-3). The, sole exception is that ICESCR ratification is positively associated with aspirational rights in the LLSV model (as well as in the Non model, see Table A4). In addition to the positive association between ICESCR ratification and aspirational ESR entrenchment, ratification of the Covenant also predicts a $30-40 \%$ increase in the number of rights present in a constitution. The year a constitution came into force is significant for both ESR presence and justiciability, with the predicted number of ESRs increasing by 1 to $1.5 \%$ per year, all else remaining constant. This finding is supportive of the "World Society" thesis advanced by Meyer et al., as well as the more generalized findings of increasing formal rights protection over time. In addition to the age of a constitution, there is also a tendency for more recently amended constitutions to contain more ESRs, but the association reaches statistical significances in only one model (LLSV-1). With regard to the two additional control variables, while Log GDP per capita is decidedly not significant, Log Population is positively associated with increased ESR entrenchment across both ESR presence and justiciability models.

These regressions are largely supportive of our earlier findings. As common law becomes less prevalent and civil law becomes more prevalent, the expected number of rights-present and justiciable-increases markedly. The models predict that, all else held constant, countries with a solely civil law tradition will have more than three-and-a-half times as many ESRs present and more than five times as many justiciable rights. It is not entirely clear whether this is because the common law tradition discourages ESR entrenchment, the civil law tradition encourages it, or a combination

\footnotetext{
104 The regression coefficients are reported in Table A3 (Appendix). For a general description of the calculation, characteristics and interpretation of Incidence Rate Ratios as compared to coefficients in Poisson and negative binomial regression, see JosePH M. HiLBE, NEGATIVE BINOMIAL REGRESSION 15-24, 109-16 (2 ed. 2011 ).

105 Put differently, the predicted value of the dependent variable for a case where $\mathrm{x}_{1}=1$ is IRR times greater (if IRR $>1$ ) or lesser (if IRR $<1$ ) than for a case where $x_{1}=0$, all else being equal. Where IRR $\approx 1$ (i.e. the confidence interval includes 1 ), the effect of $\mathrm{x}_{1}$ is not statistically significant.

106 Thus, where IRR $>1$ there is a positive relationship between the variables and where IR $<1$, the relationship is negative. An IRR equal to 1 (or a confidence interval that contains it) suggests that a variable has no effect on the dependent variable.

${ }^{107}$ Pseudo- $\mathrm{R}^{2}$ is equal 1-( $\left(\mathrm{L}_{\mathrm{f}} / \mathrm{L}_{\mathrm{i}}\right)$ where $\mathrm{L}_{\mathrm{f}}$ is the log-likelihood of the full model and $\mathrm{L}_{\mathrm{i}}$ is the log-likelihood of the intercept-only model. HILBE, supra note at 64-67.
} 
of the two. We believe the third option is the most likely, although there is some evidence that civil law may exert a stronger effect. With respect to justiciable rights, the Mixed Common law is not statistically distinct from the Pure Common law. Additionally, when the non-exclusive JuriGlobe models are considered (Table A3, Non-1/2), only the civil law tradition is significant.

Countries with a solely Islamic and/or Customary legal tradition are also expected to have substantially more ESRs present. There is, however, no significant relationship with respect to justiciability. When the LLSV classification is used to operationalize legal tradition, only the French originated civil tradition is significantly different from the UK legal tradition. Here, too, this association is particularly strong where justiciability is concerned: all else remaining constant, countries with a French legal origin can be expected to have almost two-and-a-half as many justiciable ESRs as those with a UK legal origin.

As expected, we also find that Latin America and Postcommunist countries consistently exhibit a greater number of constitutional ESRs, with models predicting between one-and-a-half and two times as many present and two to three-and-a-half times as many justiciable rights as constitutions in Western Europe and North America, all else being equal. Small Island Developing states are also positively associated with presence and justiciability in the JG models, a relationship that is significant with respect to justiciable rights (JG-2) and approaches it in the rights presence model (JG-1). Except for a positive association between Asia and ESR presence, no other regional category reaches statistical significance. No other regional categories

There are three principal takeaways from this analysis. First, time matters - the more recently a constitution was drafted, the more ESRs it is likely to contain. To a limited extent, this also applies to constitutional amendments as well. Second, countries with common law legal traditions are relatively less likely to entrench ESRs and those with civil law systems are more likely to do so. Third, independent of legal tradition and age of constitution, Latin America and Postcommunism are both associated with substantially higher levels of ESR presence and justiciability.

\section{CONCLUSION}

Despite ample normative and jurisprudential analyses of economic and social rights, there are still relatively few studies of the actual status of such rights in national constitutions. The handful of studies that attempt to measure the existence of ESRs in world constitutions draw on crude classifications that are not sufficiently detailed to reflect the considerable variance within the broad ESR category, let alone differences in the scope of various ESRs' constitutional protection. Developing and drawing upon a first-of-its-kind dataset that measures the presence and justiciability of sixteen different economic and social rights in the written constitutions of 195 countries, we demonstrate that despite global convergence with respect to constitutional rights protections, significant variance persists in the world's constitutions.

First, our analysis demonstrates that although economic and social rights have grown increasingly common in national constitutions, not all ESRs are equal. By collecting detailed data on sixteen distinct ESRs, we show that certain ESRs (e.g. a right to education) are so 
common as to be practically universal, whereas others (e.g. the rights to food or water) are still quite rare.

Second, different ESRs are also accorded different status in different constitutions. Roughly one third of all constitutions that entrench ESRs identify them as aspirational, one third identify all ESRs as justiciable, and one third distinguish among ESRs, identifying some as aspirational and some as justiciable.

Third, we find a strong positive correlation between the civil law tradition and the entrenchment of positive rights, and a negative association between ESRs and common law. Constitutions in solely civil law countries specify and protect an average of 10.0 economic and social rights, and are more likely to identify those rights as justiciable. Constitutions in solely common law countries include an average of 1.6 ESRs. Islamic and customary law countries fall between the two extremes. More broadly, these findings call into question claims of a global convergence of constitutional law.

Fourth, some regions have a regional model of ESR entrenchment, but others do not. The Postcommunist States and Latin America exhibit a strong regional norm of constitutional entrenchment and justiciability of most ESRs; the Middle East and North Africa exhibits a weak regional norm of an average number of aspirational rights and very low numbers of justiciable rights; Western Europe and North America and the Small Island Developing States both have a weak regional norm of low numbers of ESRs either present or justiciable; Asia and Sub-Saharan Africa show no regional norm. Such regional patterns partly weaken the correlation between rights and legal tradition since some regions are also highly correlated with particular legal traditions. Nevertheless, when we control for legal tradition and region, each variable continues to have an independent effect.

Further inquiry into the patterns of ESR constitutional protection, interpretation and enforcement is warranted in order to expand and complement the findings presented in this article. Economic and social rights are not constituted, interpreted, or implemented in an institutional, ideological, or political vacuum. Specifically, the prospects for advancing economic and social rights in a given polity cannot be reduced to the constitutional domain alone, and may not be effectively analysed in isolation from the concrete fiscal realities, legacies of welfare provision, historical influence of leftist political forces, public opinion on core matters of health care and education, or patterns of judicial behavior and executive-judiciary relations in that polity. In short, there are multiple paths and trajectories to the realization (or neglect) of economic and social welfare rights, of which constitutionalization is only one aspect.

Nevertheless, the formal constitutional text must serve as the conceptual and empirical baseline for any further inquiry on economic and social rights and realities. In that respect, our analysis confirms that economic and social rights are increasingly protected in national constitutions, but also that there is wide variation in which rights are enshrined, as well as how and where they are enshrined. Even with respect to the most formal and rapidly diffusing aspect of economic and social rights protection - the text of national constitutions - the world may have grown increasingly smaller, but the domestic and particular persist. 


\section{APPENDIX}

Table A1. JuriGlobe Classification Scheme

\begin{tabular}{|c|c|c|c|c|}
\hline Pure Civil Law & Laos & Comoros & Civil \& & Solomon Islands \\
\hline Albania & Latvia & Congo, DR & Common Law & Sudan \\
\hline Angola & Liechtenstein & Congo, Republic & Bahrain & Tanzania \\
\hline Argentina & Lithuania & Côte d’Ivoire & Botswana & Uganda \\
\hline Armenia & Luxembourg & Djibouti & Cameroon & Zambia \\
\hline Australia & Macedonia & Egypt & Cyprus & \\
\hline Austria & Mexico & Equatorial Guinea & Guyana & Pure Common Law \\
\hline Azerbaijan & Moldova & Eritrea & Israel & Antigua and \\
\hline Belarus & Monaco & Ethiopia & Liberia & Barbuda \\
\hline Belgium & Montenegro & Gabon & Malta & Bahamas \\
\hline Benin & Netherlands & Guinea & Mauritius & Barbados \\
\hline Bolivia & Nicaragua & Guinea-Bissau & Namibia & Belize \\
\hline Bosnia and & Norway & Indonesia & Philippines & Canada \\
\hline Herzegovina & Panama & Iran & Qatar & Dominica \\
\hline Brazil & Paraguay & Iraq & Saint Lucia & Fiji \\
\hline Bulgaria & Peru & Japan & Seychelles & Grenada \\
\hline Cambodia & Poland & Jordan & Somalia & Ireland \\
\hline Cape Verde & Portugal & Korea (North) & South Africa & Jamaica \\
\hline Central African & Romania & Korea (South), & Sri Lanka & Kiribati \\
\hline Republic & Russia & Kuwait & Vanuatu & Marshall Islands \\
\hline Chile & Serbia & Lebanon & Yemen & Nauru \\
\hline Colombia & Slovakia & Libya & Zimbabwe & New Zealand \\
\hline Costa Rica & Slovenia & Madagascar & & Saint Kitts and \\
\hline Croatia & Spain & Mali & Mixed & Nevis \\
\hline Cuba & Suriname & Mauritania & Common Law & Saint Vincent and \\
\hline Czech Republic & Sweden & Mongolia & $\overline{\text { Bangladesh }}$ & the Grenadines \\
\hline Denmark & Switzerland & Morocco & Bhutan & Tonga \\
\hline Dominican Republic & Tajikistan & Mozambique & Brunei & Trinidad and Tobago \\
\hline Ecuador & Thailand & Niger & Gambia, The & Tuvalu \\
\hline El Salvador & Turkey & Oman & Ghana & UK \\
\hline Estonia & Turkmenistan & Palestinian OT & India & USA \\
\hline Finland & Ukraine & Rwanda & Kenya & \\
\hline France & Uruguay & Sao Tome and & Lesotho & Customary and/or \\
\hline Georgia & Uzbekistan & Principe & Malawi & $\overline{\text { Muslim Law Only }}$ \\
\hline Germany & Venezuela & Senegal & Malaysia & $\overline{\text { Afghanistan }}$ \\
\hline Greece & Vietnam & Swaziland & Micronesia & Andorra \\
\hline Guatemala & & Syria & Myanmar & Maldives \\
\hline Haiti & Mixed & Taiwan & Nepal & Saudi Arabia \\
\hline Honduras & Civil Law & Timor-Leste (East & Nigeria & UAE \\
\hline Hungary & Algeria & Timor) & Pakistan & \\
\hline Iceland & Burkina Faso & Togo & Papua New Guinea & \\
\hline Italy & Burundi & Tunisia & Samoa & \\
\hline Kazakhstan & Chad & & Sierra Leone & \\
\hline Kyrgyzstan & China & & Singapore & \\
\hline
\end{tabular}


Table A2. Composition of Regions

\begin{tabular}{|c|c|c|c|c|}
\hline Middle-East \& & Pakistan & Chile & Nigeria & Small Island \\
\hline North Africa & Philippines & Colombia & Rwanda & Developing States \\
\hline$\overline{\text { Algeria }}$ & Singapore & Costa Rica & Senegal & Antigua and \\
\hline Bahrain & Sri Lanka & Ecuador & Sierra Leone & Barbuda \\
\hline Cyprus & Taiwan & El Salvador & Somalia & Bahamas \\
\hline Djibouti & Thailand & Guatemala & South Africa & Barbados \\
\hline Egypt & Vietnam & Honduras & South Sudan & Cape Verde \\
\hline Iran & & Mexico & Swaziland & Comoros \\
\hline Iraq & Postcommunist & Nicaragua & Tanzania & Cuba \\
\hline Jordan & States & Panama & Togo & Dominica \\
\hline Kuwait & Albania & Paraguay & Uganda & Dominican Republic \\
\hline Lebanon & Armenia & Peru & Zambia & Fiji \\
\hline Libya & Azerbaijan & Uruguay & Zimbabwe & Grenada \\
\hline Mauritania & Belarus & Venezuela & & Guinea-Bissau \\
\hline Morocco & Bosnia and & & Western Europe \& & Guyana \\
\hline Oman & Herzegovina & $\underline{\text { Sub-Saharan }}$ & North America & Haiti \\
\hline Palestinian Occupied & Bulgaria & Africa & Andorra & Jamaica \\
\hline Territories & Croatia & Angola & Australia & Kiribati \\
\hline Qatar & Czech Republic & Benin & Austria & Maldives \\
\hline Saudi Arabia & Estonia & Botswana & Belgium & Marshall Islands \\
\hline Sudan & Georgia & Burkina Faso & Canada & Mauritius \\
\hline Syria & Hungary & Burundi & Denmark & Micronesia \\
\hline Tunisia & Kazakhstan & Cameroon & Finland & Nauru \\
\hline Turkey & Kosovo & Central African & France & Palau \\
\hline United Arab & Kyrgyzstan & Republic & Germany & Papua New Guinea \\
\hline Emirates & Latvia & Chad & Greece & Saint Kitts and \\
\hline \multirow[t]{2}{*}{ Yemen } & Lithuania & Congo, Republic of & Iceland & Nevis \\
\hline & Macedonia & Congo, Democratic & Ireland & Saint Lucia \\
\hline Asian States & Moldova & Republic of & Israel & Saint Vincent and \\
\hline$\overline{\text { Afghanistan }}$ & Montenegro & Côte d'Ivoire & Italy & the Grenadines \\
\hline Bangladesh & Poland & Equatorial Guinea & Liechtenstein & Samoa \\
\hline Bhutan & Romania & Eritrea & Luxembourg & Sao Tome and \\
\hline Brunei & Russia & Ethiopia & Malta & Principe \\
\hline Cambodia & Serbia & Gabon & Monaco & Seychelles \\
\hline China & Slovakia & Gambia, The & Netherlands & Solomon Islands \\
\hline India & Slovenia & Ghana & New Zealand & Suriname \\
\hline Indonesia & Tajikistan & Guinea & Norway & Timor-Leste (East \\
\hline Japan & Turkmenistan & Kenya & Portugal & Timor) \\
\hline Korea (North), DPR & Ukraine & Lesotho & Spain & Tonga \\
\hline Korea (South), & Uzbekistan & Liberia & Sweden & Trinidad and Tobago \\
\hline Republic of & & Madagascar & Switzerland & Tuvalu \\
\hline Laos & Latin America & Malawi & United Kingdom & Vanuatu \\
\hline Malaysia & Argentina & Mali & United States of & \\
\hline Mongolia & Belize & Mozambique & America & \\
\hline Myanmar & Bolivia & Namibia & & \\
\hline Nepal & Brazil & Niger & & \\
\hline
\end{tabular}


Table A3.

Negative Binomial Regression Models (Regression Coefficients \& Standard Errors)

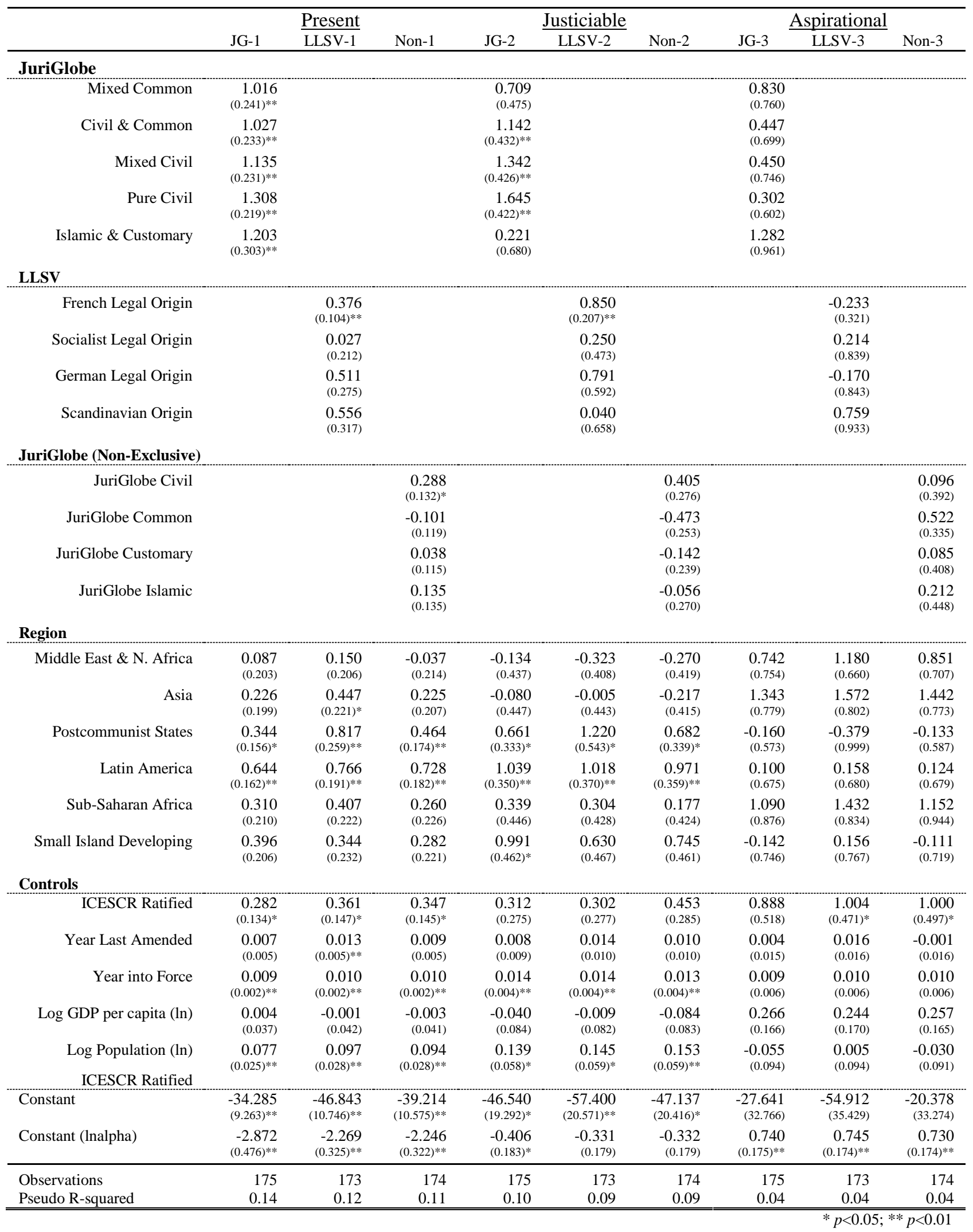

